\title{
Flexural basin reworked by salt-related pull-apart structures: the Adony Basin
}

\author{
Márton Palotai* \\ Department of Geology, Eötvös Loránd University \\ Budapest
}

\author{
László Csontos \\ MOL PLC., Budapest
}

Several main tectonic lineaments originating in the Alps and Dinarides merge in Central Hungary to form the Mid-Hungarian Shear Zone. As these structures are hidden beneath sub-basins of the Neogene Pannonian Basin, it has long been debated whether the tectonic style of the shear zone is mainly contractional or strike-slip. New 3D seismic data allowed a detailed analysis of one of these sub-basins, the Adony Basin, located south of Budapest. Its evolution is linked to the tectonics between the southern Tisza unit of European passive margin affinity, the northern ALCAPA block with Alpine affinity, and sheared remnants of Dinaric units in between. During the Oligocene and Early to Middle Miocene, a flexural basin related to the convergent thrusting of Dinaric- and ALCAPA-derived units was developed. On the southern side, N-NW verging thrust sheets were observed. On the opposite front, Triassic carbonates of ALCAPA were thrust several kilometres above Palaeogene formations to the SW. Dextral transpression is assumed for the Middle Miocene. Local deposition of Middle Miocene salt in the basin formed a detachment surface. Late Miocene sinistral strike-slip faulting resulted in a pull-apart basin above that part of the earlier flexural basin that has not been overthrust. The margins of the basin coincided with the fronts of earlier thrusts. Faults on the basin margins partly detached on the salt, decoupling the supra-salt basin fill from the underlying formations. Within the pull-apart basin, gravity sliding on the steep margins resulted in salt welds, detachment and roll-over folds.

Key words: strike-slip faults, pull-apart basin, salt tectonics, flexural basin, Pannonian Basin, MidHungarian Shear Zone

Addresses: M. Palotai: H-1117 Budapest, Pázmány P. sétány 1/c, Hungary e-mail: palotai@elte.hu

L. Csontos: H-1117 Budapest, Október huszonharmadika u. 18, Hungary e-mail: lcsontos@mol.hu

Received: February 26, 2013; accepted: March 5, 2013 


\section{Introduction}

The continuation of the major Alpine tectonic lineaments towards and beneath the Pannonian basin, Hungary (Fig. 1), has been in the focus of interest since modern subsurface data became available (Wein 1969, 1978; Kőrössy 1981; Fülöp and Dank 1987; Schmid et al. 2008; Haas et al. 2010). The question is important indeed, since there is only quite limited direct information from the basement of the Neogene Pannonian basin in the form of isolated inselbergs (Fig. 2A). Based on lithostratigraphic correlation of these inselbergs as well as borehole material, many authors have delineated the possible tracks of these important tectonic lineaments. However, one of the most important features, the Mid-Hungarian Line, has still many uncertainties.

Both the Periadriatic Line (or its proposed continuation, the Balaton Line) and the Mid-Hungarian Line are key elements in the tectonics of the Intra-Carpathian area. As defined by Wein (1969), Balla and Dudko (1989) and Fodor et al. (1999), the Balaton Line separates the Transdanubian Range of South Alpine origin in the northwest from the Mid-Hungarian Unit in the southeast (Fig. 2C). Entering the Pannonian Basin from the west, the Balaton Line (Fig. 2C) disappears somewhere west of Adony Basin, only to apparently continue in the eastern Tóalmás Line (Tari et al. 1992; Csontos and Nagymarosy 1998; Fodor et al. 2005; Palotai and Csontos 2010, Fig. 2C). This continuation and the link, or eventual relay of these lineaments remains uncertain because of limited information in intermittent zones and/or thick volcanic cover.

All these structures have a linear aspect on the subsurface maps of the Pannonian basin (Fülöp and Dank 1987; Haas et al. 2010; Fig. 2) and they subdivide the basement of the Pannonian basin into three parts along a WSWENE direction. Their intermittent zone is characterised by a series of deep rhomboidal sub-basins (Fig. 2B, C), which hint to their strike-slip origin (Royden et al. 1983; Kázmér and Kovács 1985; Fodor et al. 1999). However, based on other data, some authors proposed a compressional origin for these basins (Balla 1987; Csontos and Nagymarosy 1998; Csontos et al. 2005). The aim of this paper is to contribute to this debate by showing the complex origin of the Adony Basin, which serves as a case study in this important tectonic zone.

We demonstrate that a peculiar salt horizon also takes part of the structural development. Salt tectonics in extensional and contractional settings has been extensively studied, but relatively few studies (e.g. Smit et al. 2008) have dealt with salt-related features in strike-slip regimes. Acting as a décollement layer, evaporites decouple the supra-salt basin infill from basement structures. The focus of our study is a unique salt-related pull-apart basin, and we argue that the strike-slip basin is partly detached from the sub-salt layers.

Fig. $1 \rightarrow$

A) Major terranes of the Alpine and Carpathian region (after Csontos and Vörös 2004). B-E, Palaeogeographic and tectonic reconstructions for the Eocene (B), Late Oligocene (C), Middle Miocene (D) and Late Miocene-Pliocene (E) (after Csontos and Vörös 2004). See explanation in the text 

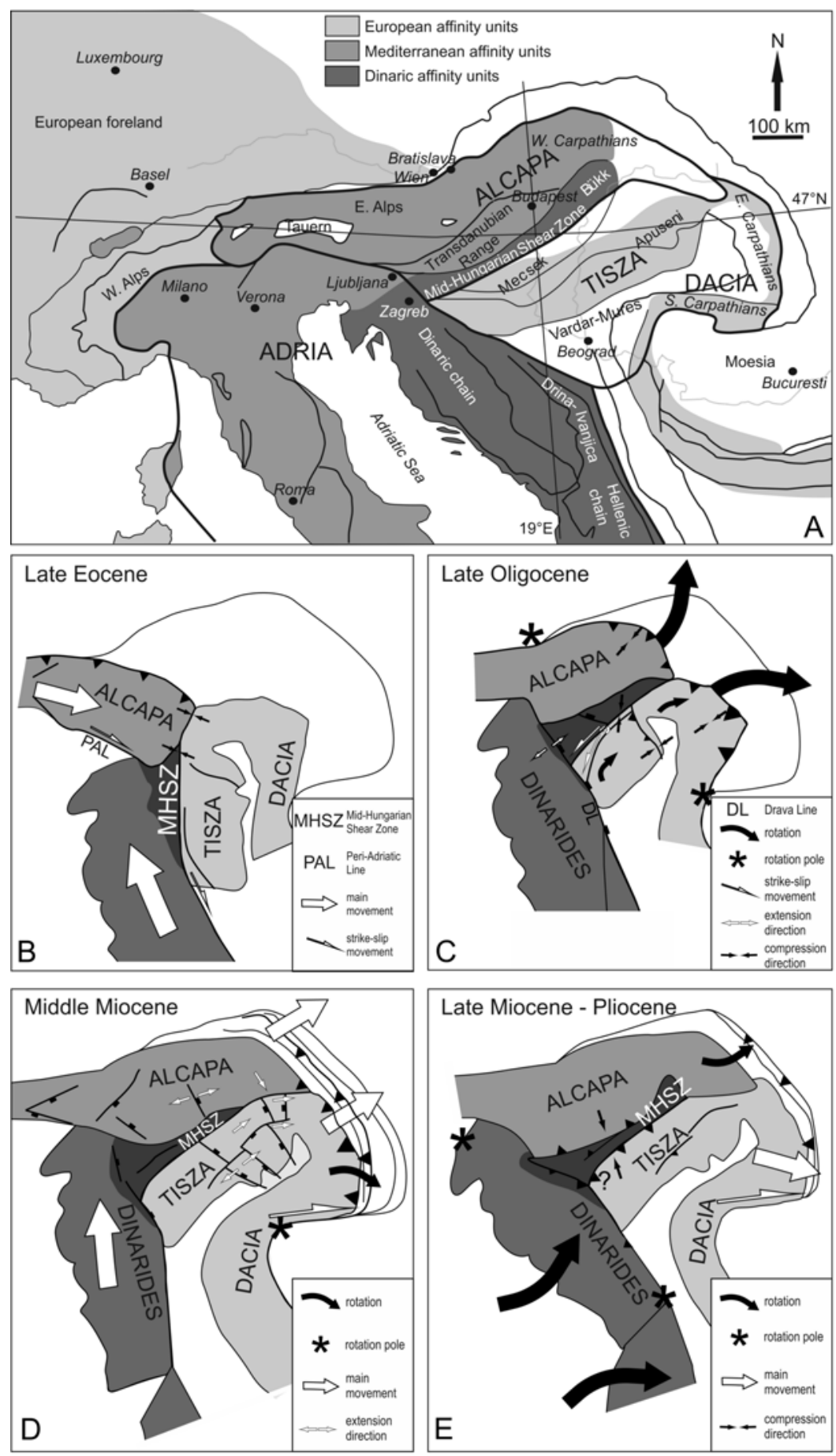


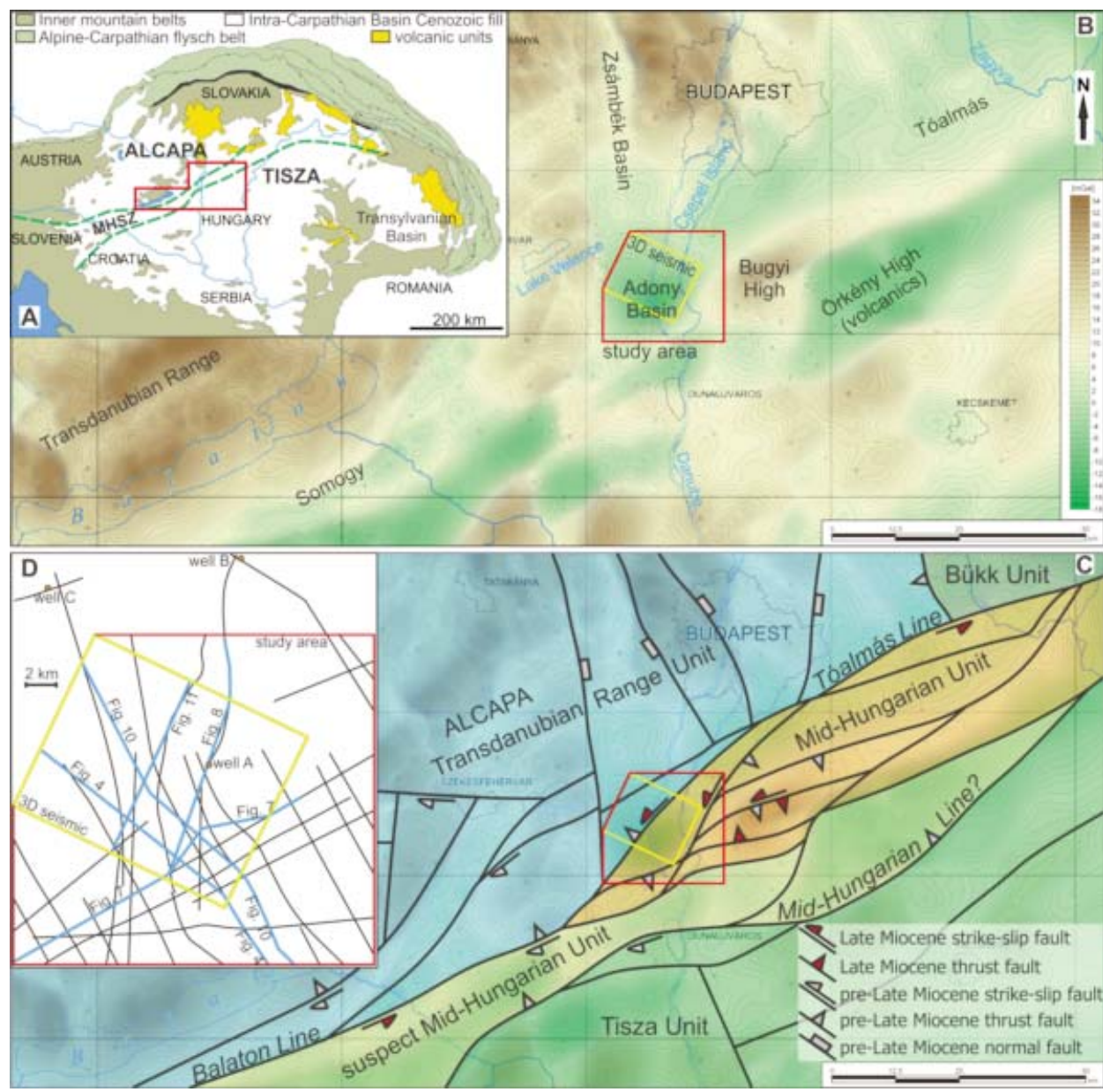

Fig. 2

Location and geological setting of the study area. A, Simplified geological map of the Pannonian region. Red polygon shows the location of map B. MHSZ: Mid-Hungarian Shear Zone. B, Bouguer gravity anomaly map of central Hungary (Gulyás 2005). C, Tectonic interpretation of central Hungary. Fault lines modified from Haas et al. (2010), kinematics taken from Csontos et al. (2005), Palotai and Csontos (2010), Fodor (2010) and own unpublished data. D, Location map of the study area with wells (orange dots), 2D seismic lines (black lines) and the 3D cube. Blue lines indicate sections shown in this study

\section{Tectonic setting}

To characterise the geology of Hungary, three different terranes, the ALCAPA (Alpine-West Carpathian-Pannonian; Faupl et al. 1997) the Tisza-Dacia and the Mid-Hungarian Units were defined mainly on lithostratigraphic grounds and regional correlation with the surrounding mountain belts (Fig. 1A; Wein 1969, 
1978; Géczy 1973; Balla 1984, 1999; Kázmér and Kovács 1985; Csontos et al. 1992; Channel and Horváth 1976; Kázmér and Kovács 1985; Haas et al. 1995; Csontos and Vörös 2004; Kovács I. et al. 2007; Kovács S. et al. 2010). The Mid-Hungarian Unit has been considered as part of ALCAPA by several authors (e.g. Balla 1984; Csontos and Vörös 2004). However, we suggest to retain a tripartite subdivision, because of the markedly different deformation history of the three units. Synchronous with lithostratigraphic work, important paleomagnetic (Márton 1985; Márton and Márton 1989) and palaeontologic (e.g. Géczy 1973, 1984; Vörös 1993) studies were published. These suggested (1) major, opposite rotation of the Intra-Carpathian terranes (Fig. 1B-E), and (2) a tectonic change-over of Mesozoic faunas of southern, Apulian affinity now found in the north, with northern, European affinity faunas now in the south (for a summary see Csontos and Vörös 2004).

The contact zone of the northern and southern terranes (i.e. the MidHungarian Shear Zone, or more precisely, the Mid-Hungarian Line) was suggested to be a major strike-slip fault, along which ALCAPA and Tisza-Dacia were juxtaposed (e.g. Géczy 1973, 1984; Flügel 1975; Kovács S. 1982; Csontos et al. 1992). The time of activity of this supposed strike-slip fault was proposed as Late Eocene (Kázmér and Kovács 1985; Fodor et al. 1992) or Late Oligocene-Early Miocene (Csontos et al. 1992) or even Middle to Late Miocene (Balla 1984; Balla et al. 1987).

Based on the Márton couple's palaeomagnetic work, Mészáros (1984), Balla (1984) and Csontos (1995) proposed that the major units underwent large en bloc rotation (Fig. 1B-E), which led to their final juxtaposition. In that model, the MidHungarian Shear Zone functioned as a subduction scar or a major compressional belt during the Early to Middle Miocene (see also Balla et al. 1987). Since no major mountain belt, but a set of deep basins is located along this zone, Csontos and Nagymarosy (1998) and Csontos et al. (2005) suggested that significant alongstrike extension took place simultaneously to along-dip shortening (see also Tomljenović and Csontos 2001).

\section{Stratigraphy of the broader study area}

The stratigraphy of the immediate surroundings of the Mid-Hungarian Shear Zone is summarized as follows (Fig. 3). The northern unit, ALCAPA, comprises Palaeozoic to Mesozoic sequences. Their best exposures are in the Transdanubian Range, north of Lake Balaton (Fig. 2B). The succession has high similarity to that of the Southern Alps, and hence to the Apulian indenter. Mesozoic rocks are nonmetamorphosed and are gently deformed by mid-Late Cretaceous deformation events. Crystalline basement rocks are rare; some Late Variscan granites and Palaeogene tonalites are found along the Balaton Line, the supposed continuation of the Periadriatic Line (Fülöp and Dank 1987). 

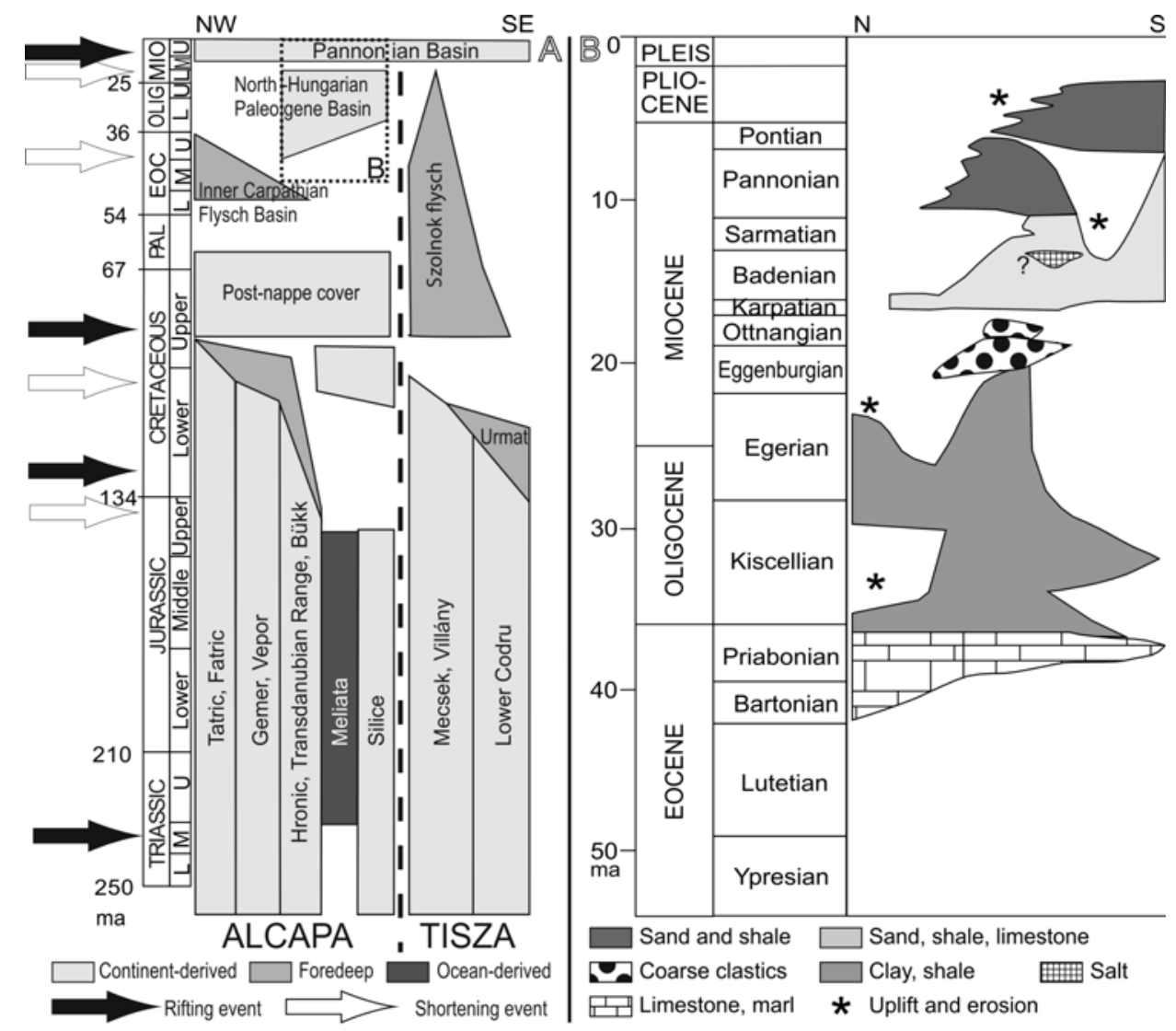

Fig. 3

A, Simplified diagram of the main nappe units and structural phases of the internal parts of the Carpathian Basin (after Csontos and Vörös 2004). Dotted rectangle shows the location of B. B, Simplified lithostratigrahic column of the North Hungarian Palaeogene and Neogene basins (modified after Csontos and Nagymarosy 1998)

In the Mid-Hungarian Unit, boreholes penetrated a basement very similar to the NE Hungarian inselbergs (Bükk, Szendrő-Uppony) (Juhász 1964; Bérczi-Makk 1978; Balla et al. 1987; Haas et al. 2010; Kovács and Haas 2010). This unit consists of gently metamorphosed (anchi-zone) Palaeozoic-Mesozoic rocks (Árkai et al. 1995), highly deformed into several nappes, and includes ophiolite remains. Strong similarities to Internal Dinaric units have been noted (Wein 1978; Kovács I. et al. 2007; Kovács S. et al. 2010). However, the distinction from the formations in the Transdanubian Range is doubtful in a number of boreholes (Kovács and Haas 2010).

On the southern side of the Mid-Hungarian Line, in the Tisza terrane, at least five major Cretaceous nappe complexes have been defined. High-grade 
crystalline basement rocks are abundant (Cserepes-Meszéna 1986) in the northern nappe units (Mecsek, Villány-Bihor). Coupled with Upper Variscan granites (Buda 1992) they form the substratum of a non-metamorphosed Mesozoic sequence. This has clear European, Germanic affinities, at least in the Permian-Early Jurassic period (Géczy 1973, 1984; Kovács S. 1982; Vörös 1993).

Upper Cretaceous strata are exposed in the Transdanubian Range (Haas 1999), where they form a post-orogenic molasse sequence. This local basin is quite similar in stratigraphy and type to the Austrian Kainach basin (Neubauer et al. 1995). Upper Cretaceous rocks are practically absent from the Mid-Hungarian Shear Zone. To the south of the Mid-Hungarian Line, Upper Cretaceous deep marine red marl occurs, laterally grading into conglomerates and deep marine clastics (Szentgyörgyi 1989). All these formations cover the nappes of the TiszaDacia terrane in several roughly E-W oriented troughs, the northernmost of which is called Szolnok trough (Szepesházy 1973; Szentgyörgyi 1989).

Palaeogene to Early Miocene sequences strongly differ on the two sides of the Mid-Hungarian Line. To the north a uniform, but locally variable, nonmetamorphic sequence is developed in both the ALCAPA and Mid-Hungarian Units. Basal Upper Eocene clastic units are overlain by limestones, followed by deep marine marls. In the Oligocene, after a widespread anoxic event, deep marine clays were deposited. Lower Miocene sandstones, siltstones and shales developed in shallower and deeper parts of the basin, respectively (Báldi and Báldi-Beke 1985; Nagymarosy 1989; Tari et al. 1993). The local sequences are very different, however: some parts have thin, coarse clastic deposits (on possible ridges), whereas others have thick deep marine sediments (in possible local depocentres; Lakatos et al. 1992). Lower Miocene shallow marine, upwards fining sandstone or deeper marine silt covers the Oligocene (Sztanó and Tari 1993). This series is similar to equivalent beds in northern Croatia and NE Slovenia (Drobne 1977; Csontos and Nagymarosy 1998). It seems that the Periadriatic-Balaton lineament cuts the original Palaeogene basin in half.

Ongoing volcanic activity is indicated by many tuff horizons in the Palaeogene deposits of the Mid-Hungarian Unit. Strong local differences exist however: thick tuffs and lava flows were observed in some boreholes, while in nearby boreholes such tuffs are practically absent. This indicates that in addition to the original topography, later tectonic events are at least partly responsible for the variability of the stratigraphy.

On the southern side of the Mid-Hungarian Line, Palaeogene rocks are restricted to the Szolnok trough. Here the Palaeogene deposits are mostly marine clastics (some turbiditic sandy layers in the Eocene), while the Oligocene is represented mainly by shales (Nagymarosy and Báldi-Beke 1993). The Lower Miocene is missing.

Middle and Upper Miocene deposits cannot be differentiated in the ALCAPA, Mid-Hungarian and Tisza terranes. These rocks form the infill of the Pannonian Basin, which rests unconformably on older formations (Fig. 3). The Middle 
Miocene package is considered the syn-rift (Royden et al. 1983; Horváth 2007) fill of the basin, with local grabens and half-grabens. The deposits strongly differ according to local facies and include shallow water limestones and deep marine clays. Except for a single locality west of Budapest (Zsámbék basin; Jámbor 1969; Fig. 2B), no salt deposits have been described from the Middle Miocene. This is quite surprising as there are thick contemporaneous salt deposits in the Carpathian foredeep and in the central Transylvanian Basin (Krézsek and Filipescu 2005; Fig. 2A). In the Middle Miocene, the vicinity of the lineaments is also marked by the abundance of thick calc-alkaline volcanic rocks (Balla 1984; Balla et al. 1987; Tari 1994; Kovács I. et al. 2007). Upper Miocene deposits are members of a prograding delta fill with pronounced thickness variations. Generally, the Late Miocene (Pannonian stage in regional stratigraphic terminology; Fig. 3) is considered to be a non-tectonic, post-rift sag phase (Royden et al. 1983), but this is subject to debate (see later).

\section{Local geologic setting}

The Bouguer anomaly map of central Hungary (Gulyás 2005; Fig. 2B, C) shows a significant depression in the study area (Adony Basin), which has been known for a long time. However, no clear formation mechanism has been proposed so far, despite the large number of regional studies that at least marginally overlap with the current study area (Pogácsás et al. 1989; Balla 1999; Csontos and Nagymarosy 1998; Fodor et al. 1999; Csontos et al. 2005; Horváth 2007; Ruszkiczay-Rüdiger et al. 2007; Horváth and Dombrádi 2010; Palotai and Csontos 2010; Pogácsás et al. 2011). 2D seismic sections revealed the basic geometry of the basin, but, quite surprisingly, no detailed interpretation has been published so far. Based upon analogies with the area of Lake Velence (Fig. 2B), Dudko (2004) suggested an Early Miocene age for the basin, but stated that 'its formation mechanism is unknown'. Márton and Fodor (2003) suggested an early Late Miocene (Pannonian) extensional origin. Fodor (2010) also argued for an extensional origin of the basin, but the time interval was rather unconstrained, ranging probably from the Ottnangian to late Pannonian (18-5 Ma). More detailed studies in the area have been possible after the recent acquisition of $3 \mathrm{D}$ seismic data by MOL.

Being part of the Central Paratethys, regional stages are used in the Oligocene and Miocene (Báldi T. 1983; Piller et al. 2007; Fig. 3). Pannonian (Late Miocene) ages are inferred from the regional study of Magyar (2009). In this sense (Figs 3 and 4), the interpreted horizon $\mathrm{Pa} 3$ is right between time horizons of $8.0 \mathrm{Ma}$ and 8.6 Ma Pa2 is slightly younger than $10.65 \mathrm{Ma}$, while Pa1 lies above the base of Pannonian formations, i.e. between 11.6 Ma (Piller et al. 2007) and 10.65 Ma.

The most interesting peculiarity of the Adony Basin is the occurrence of salt deposits. Located at the northwestern margin of the basin, well A (Figs 2D and 8) drilled almost 200 metres of halite in the pre-Pannonian sequence (Fig. 3B). 
Although the drilling report of the parent company argues for its Badenian age, the $32 \mathrm{~m}$-thick marl/claystone sequence immediately below the base of Pannonian might be Sarmatian, as a mixed flora of Sarmatian and Badenian taxa was described from this section. Below this, $197 \mathrm{~m}$ of evaporites (mostly halite, with some intercalated shale) were penetrated. The succession below the salt yielded Lower Badenian sporomorphs. Apart from this well, no salt is known in any borehole nearby.

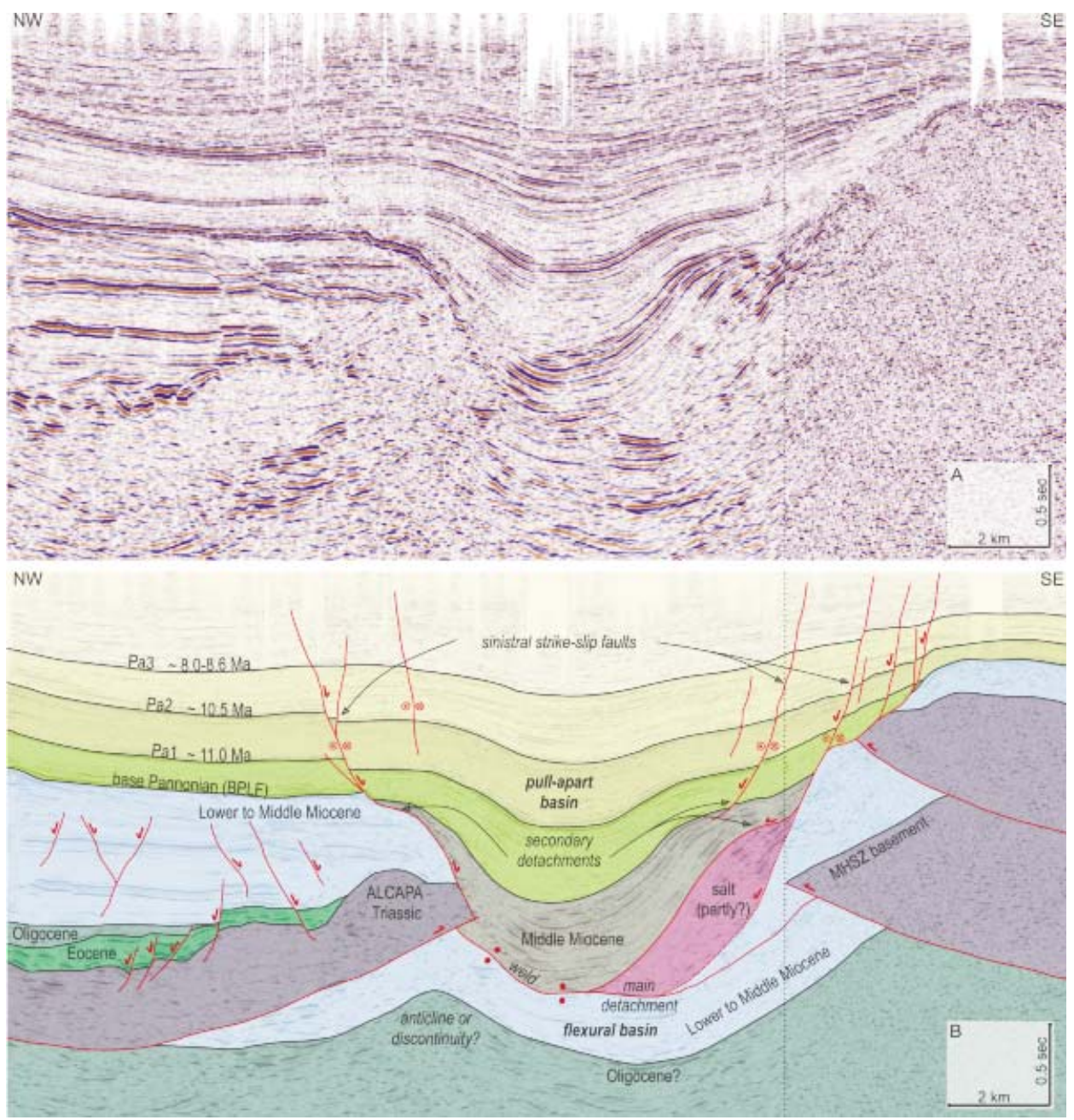

Fig. 4

Uninterpreted (A) and interpreted (B) seismic section across the basin. For location see Fig. 2D. Oligocene and Lower/Middle Miocene formations are overthrust from both sides. Pannonian age faults detach near BPLF, the detachment being continued into the basin as a salt weld. The antiform in the Oligocene is at least partly an artifact related to velocity pull-up 


\section{Materials and methods}

Our study is based upon the interpretation of a 3D seismic survey $\left(190 \mathrm{~km}^{2}\right)$ and adjacent 2D lines, covering an area of $480 \mathrm{~km}^{2}$ (Fig. 2D). The study area was chosen to include the whole Adony Basin and its margins. Unfortunately, the 3D cube does not extend over the whole basin, leaving its southern termination less constrained than the northern parts. A 3D model of the area has been built to improve visualization and reveal spatial relationships. In the study area only one borehole reached the pre-Pannonian units, but a few wells further away could also be used for correlation (Fig. 2D). Grids of horizons were created from 3D and $2 \mathrm{D}$ data together. In order to avoid losing details gained from 3D, grids were only slightly smoothed, occasionally resulting in local errors in the $2 \mathrm{D}$ domain. No depth conversion has been undertaken since this is still an ongoing project at the parent company and reliable velocity data are not yet available. This means that distortions from velocity effects are to be dealt with.

The formations were defined in the calibrating wells (Fig. 2D) and carried to the 3D volume. The seismic definition of some older horizons (especially the Palaeogene ones) is less satisfactory, because of wedge-outs or fault offsets. However, the characteristic Neogene stratigraphic formation tops could be defined in the seismic (Fig. 4).

Structural restoration was attempted for a couple of sections. This work carries some errors, because an important part of the motions took place possibly parallel, rather than perpendicular to dip line orientations. However, the method was used to get an idea about the amount of shortening and the successive paleotopographies.

\section{The pull-apart basin of Pannonian age}

\section{The strike-slip fault zone}

The well resolved Pannonian-age sinistral Tóalmás Zone (Fodor et al. 2005; Ruszkiczay-Rüdiger et al. 2007; Palotai and Csontos 2010) can be traced from the NE on 2D lines. When entering the 3D cube, a strong, nearly planar fault and related seismic damage zone (Iacopini and Butler 2011) with significant normal offset is observed. It cuts through even uppermost Pannonian reflections, although the majority of offset is in the Early Pannonian. It can be traced from the $\mathrm{NE}$ in $3 \mathrm{D}$ for ca. $5 \mathrm{~km}$, then the deep seated master fault disappears, and only faults within the Pannonian sequence are observed. This coincides with the northern margin of the basin.

En echelon faults along the northwestern basin margin are characteristic for the Pannonian sequence. 3D mapping revealed their geometry (Fig. 5). Relay patterns are clearly right-stepping, while in section view, faults generally have normal offset. Fault geometries are best observed on the Pa1 surface TWT (two-way travel time) depth map (Fig. 6C). All these faults detach at or around the base of 


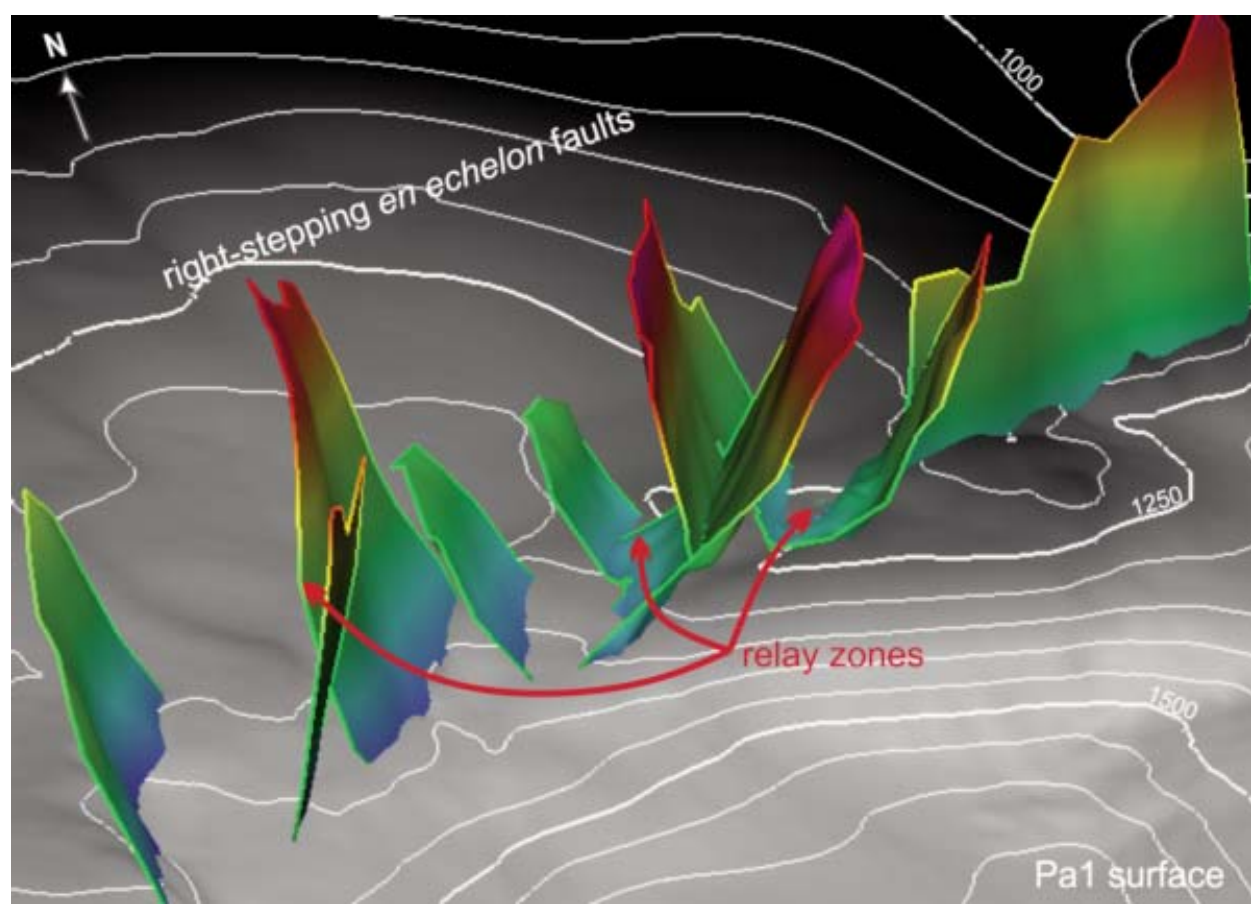

Fig. 5

Oblique view of strike-slip faults on the northwestern basin margin coloured for TWT (two-way travel time) depth, above the Pa1 surface. Note the sinistral character of the zone, with relay structures between individual faults. Pa1 depth is shown in TWT (msec). Scale varies in this perspective

Pannonian lake formations (BPLF), generally at the very margin of the basin itself (Fig. 4).

Young faulting on the other, southeastern side of the basin is much less constrained as the basin margin is close to the $3 \mathrm{D}$ cube boundary. A number of normal faults offsetting even the uppermost reflections seem to detach around BPLF at the steep slope of the eastern high (Fig. 7). We assume that they were formed at least partly by strike-slip movements.

\section{Pannonian basin architecture}

The Pannonian-age basin fits the lazy-S-shaped pull-apart basin category of Mann et al. (1983) and Mann (2007), indicating an early intermediate stage of basin evolution.

Thickness variations can be used as a simple tool for detecting synsedimentary deformation. Although compaction might modify local thicknesses, the general characteristics are thus revealed. Pannonian thickness maps (Fig. 6) show the evolution of the pull-apart basin. 
158 M. Palotai, L. Csontos
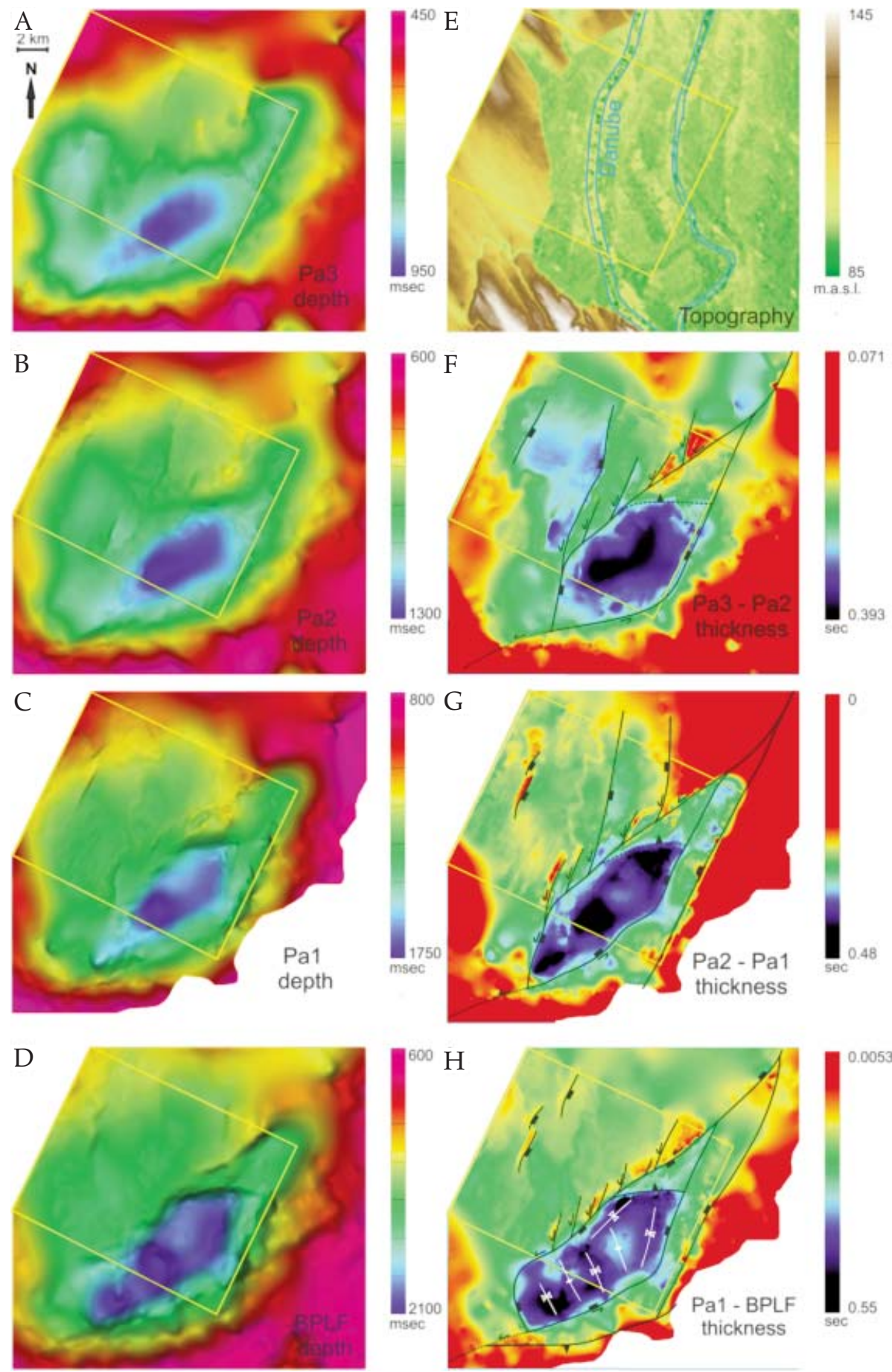

Central European Geology 55, 2012 
The most intense subsidence took place in the earliest Pannonian (Fig. 6D and $\mathrm{H}$ ), approximately before the deposition of the Pa1 horizon (Figs 4, 7, 8). The deepest part of the basin is segmented by two synsedimentary anticlines, creating three minor sub-basins. The NE-SW oriented northwestern margin is the most pronounced one, hosting only thin Early Pannonian deposits and having a rift shoulder aspect. This is due to the detaching faults that cut off the hanging wall. At these times, this margin largely behaved as a strike-slip fault zone, with probable normal components.

Being outside the 3D cube, the other margins of the basin are less clearly cut. Although the NE-SW oriented SE margin was earlier defined by two large southdipping thrust sheets (see later), we infer left lateral offsets along this fault zone.

The eastern and western basin edges (Fig. 6) are also quite linear, though appear somewhat more diffuse due to $2 \mathrm{D}$ seismic limitations. These sidewall faults are mainly normal ones (Fig. 7) as expected in pull-apart settings. On the eastern, NNE-SSW striking border, two main normal faults were mapped. At the southwestern tip of the basin, passive listric normal faulting (Fig. 7) deepened the basin. Both eastern and western margin normal faults detach on a strong reflector package with disturbed upper and relatively flat lower horizons.

A similar scenario is seen between $\mathrm{Pa} 1$ and $\mathrm{Pa} 2$ ages as in the earliest Pannonian (Fig. 6B, C, G), with some important differences. Detachment folding continued in these times. The same applies to local (strike-slip related) thrusting on both the southern margin of larger, and the northern one of smaller lateral extent. Strikeslip faulting on the northwestern margin became dominant at these times. This is reflected in the en echelon array of thinner and thicker zones on the thickness map. The southwestern tip of the basin became sharper than before, most likely because faults were more active here at this time interval.

Between Pa2 and Pa3 (Fig. 6A, B, F), i.e. in the later Pannonian, the general subsidence of the basin continued in a much more gentle way. Instead of intense faulting, a gentle syncline (possibly a sag) was formed above the earlier trough. Fault segments propagating as high as Pa3 had only minimal dip-slip offset. We assume the amount of strike-slip also decreased at these times, although we lack direct evidence for this. The previously elongated southern tip of the basin ceased to take part in intensive subsidence, resulting in a more rounded basin shape. Although two sub-basins within the strike-slip basin can still be observed on the thickness map, the relative importance of detachment folding decreased.

$\leftarrow$ Fig. 6

Top view of Pannonian TWT (two-way travel time) depth surfaces (A-D), TWT thickness maps with structural interpretation $(\mathrm{F}-\mathrm{H})$ and the present day topography $(\mathrm{E})$. Yellow rectangles indicate the 3D seismic volume. More details in the text 


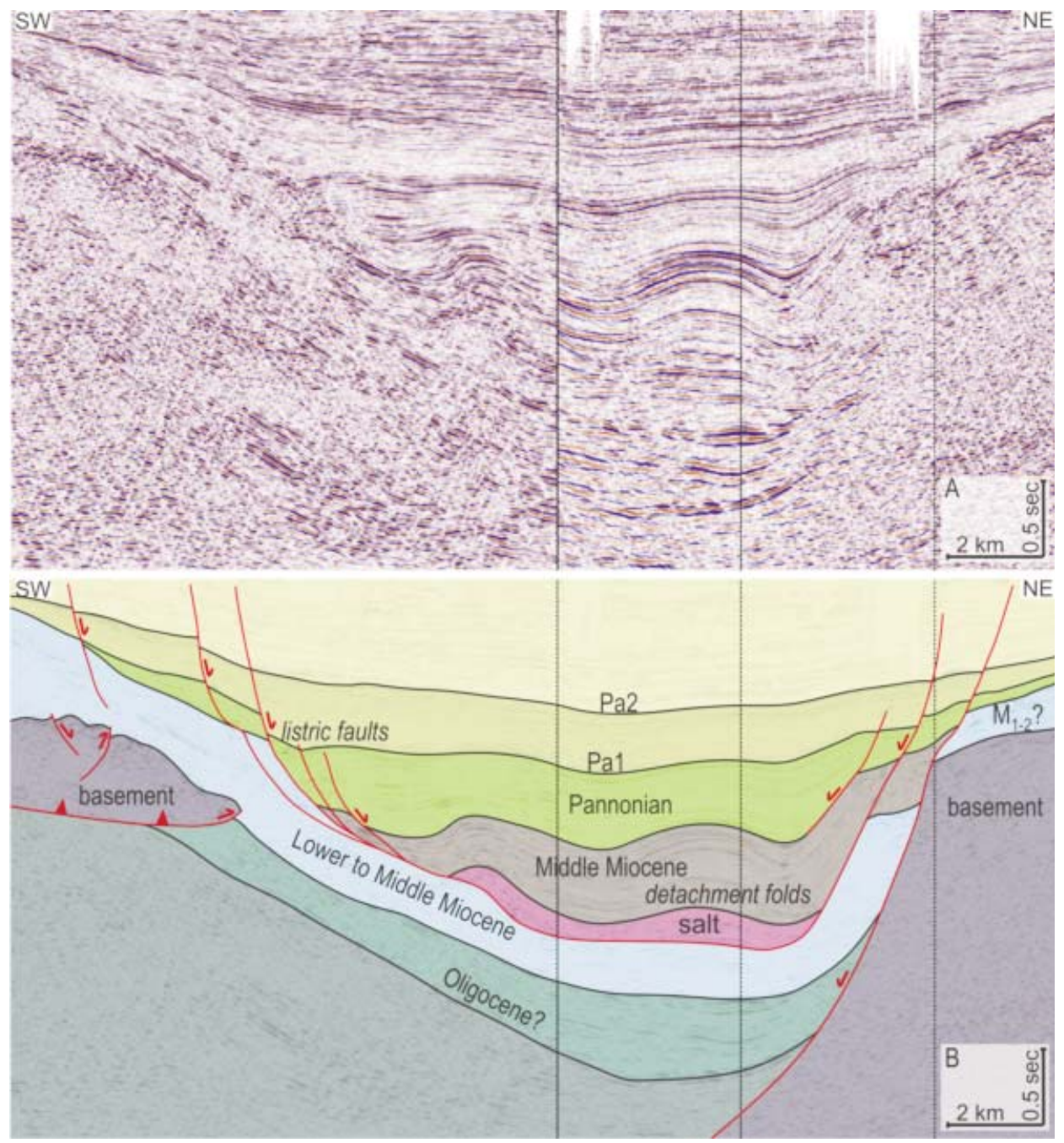

Fig. 7

Uninterpreted (A) and interpreted (B) seismic section along the basin. For location see Fig. 2D Pannonian faults on both basin margins detach at the horizon also forming the detachment folds in the basin. Note the deep-seated normal fault in the NE

\section{Salt tectonics}

The central part of the basin infill forms a detachment fold train. The main detachment horizon is quite well constrained in the area of 3D seismic, but can also be followed on 2D lines in the axis of the basin (Fig. 7). Two detached anticlines were mapped. Both are four-way closed domes, although the southern 
one is less well constrained due to $2 \mathrm{D}$ seismic data limitations. The arrangement of folds does not show an en echelon manner.

The southwestern tip of the basin is a set of listric normal faults detaching at a specific level that can be followed below the detachment fold (Fig. 7). This level can also be regarded as a multiply listric fault surface, as the southwestern rollover anticline in the basin lies over a deeper ramp. No ramp is found below the other anticline, but small scale thrust ramps detaching mainly at the same level were mapped (Fig. 7), coring the anticline. Reflections below the detachment are continuous in the basin area on 3D seismic, and are bent into a gentle syncline (Figs 4,7 ). The detachment horizon ends at the eastern margin of the basin, indicating that sub-salt strata were involved in faulting here. At the northwestern basin margin, however, the detachment horizon seems to continue below the Triassic (Figs 4, 11). At the current resolution, no clear seismic basement can be detected.

Salt is offset to be found at much shallower depth in well A (Fig. 2D). The salt drilled here (Fig. 8) is not well imaged on seismic data, and cannot be traced as a continuous zone farther away. Being in the heavily fractured marginal fault zone, repetitions of salt and/or halokinetic movements are likely.

With salt drilled at the northwestern margin, and a detachment horizon in the basin, we assume an originally continuous salt layer in the basin and at its very margins that has been offset. Although we cannot exclude shale tectonics, it is much more likely that salt, once present, would act as the detachment layer, rather than assuming a separate shale décollement at another stratigraphic level.

Figures 4,7 and 8 show that the supra-detachment layers are extremely variable in thickness. We attribute this to salt movement, even welding. There is a pronounced asymmetry of welding: the northwestern portion of supra-salt deposits is generally thicker above the weld, while salt thickness increases to the east-southeast (Fig. 4).

\section{Thrusts of Pannonian age}

A small E-W striking segment separates the deepest part of the basin from the little triangular zone in the front of the ridge on the northern side of the basin (Fig. 6). This is caused by a north dipping thrust active in early Pannonian times (Figs $6 \mathrm{H}$ and 8 ) that created a pronounced subsiding area in its foreland. We assume north verging thrusts on the southern edge of the basin being active in the early Pannonian, but these structures mainly acted as blind faults.

All these features (as well as extensional structures described above) are in accordance with a strike-slip tectonic regime in a stress field with north-south compression and perpendicular extension. 


\section{Continuation of strike-slip}

As mentioned before, the Tóalmás Zone (mapped in detail by Palotai and Csontos 2010) appears in the area from the northeast as a well-developed

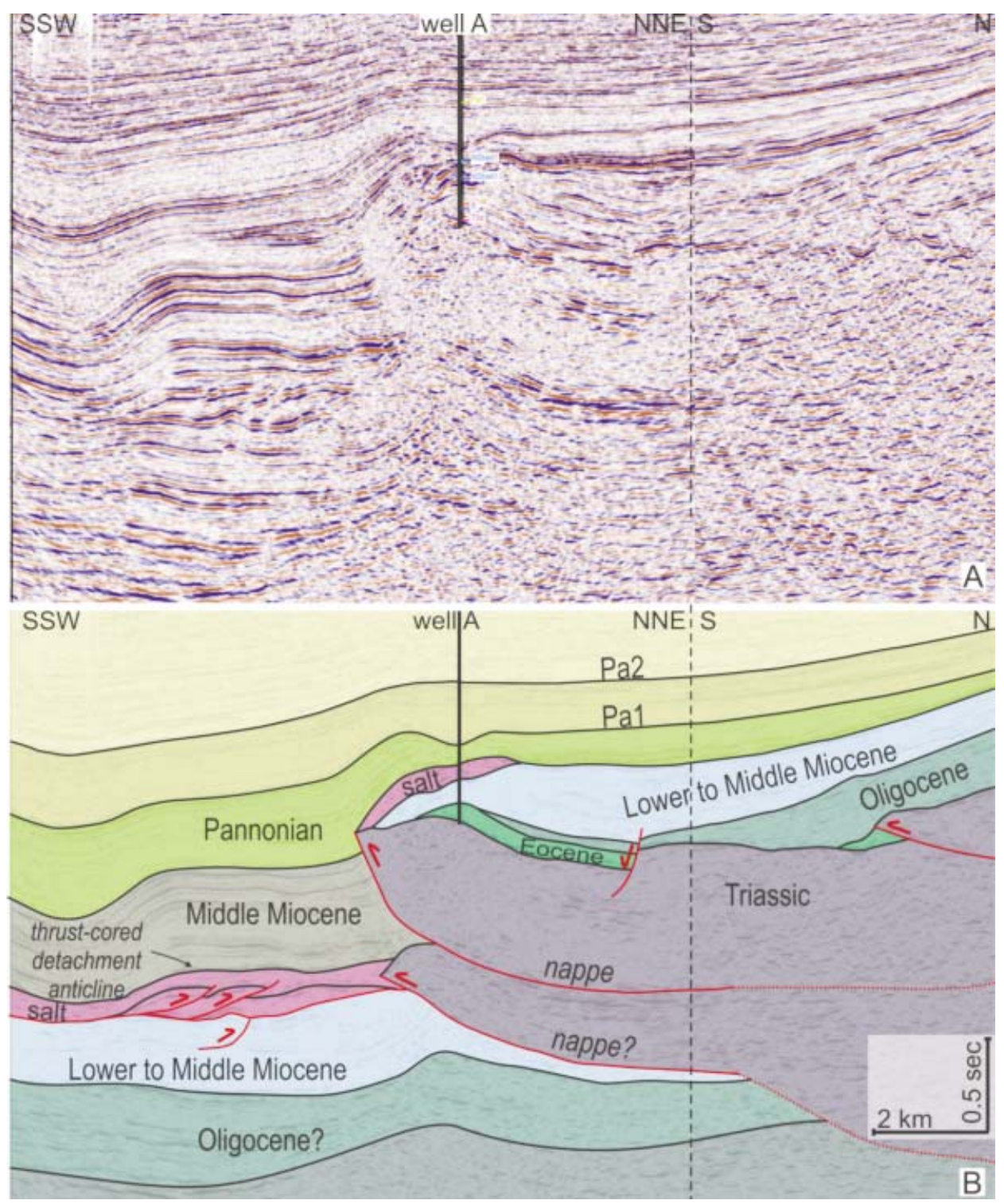

Fig. 8

Uninterpreted (A) and interpreted (B) seismic section along the basin axis through well A. For location see Fig. 2D. Thrust sheets displace the salt. Note the detachment fold cored by minor thrusts in the basin 
Pannonian age left-lateral strike-slip zone. Southwest of the studied basin, however, it can hardly be traced on 2D lines. Cross-sections through the Adony Basin (Figs 2, 4, 7, 8, 10) reveal that Pannonian age strike-slip faults detach at or just below the base of Pannonian formations on both sides of the basin. We assume that the gross amount of shallow slip of the zone is taken up by the studied basin - more specifically by the salty detachment horizon. This may result in the loss of continued strike-slip motion immediately to the southwest of the study area.

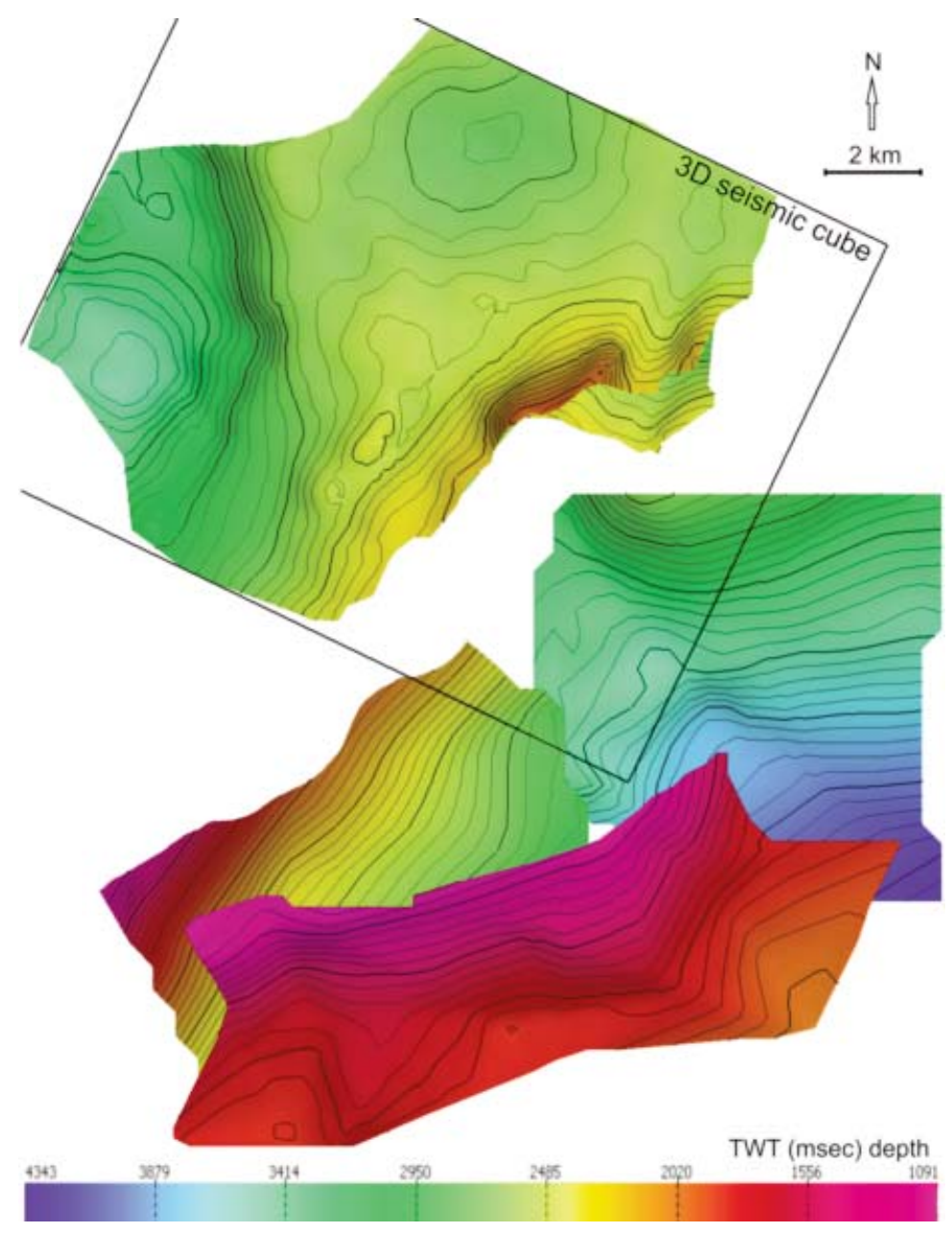

Fig. 9

TWT (two-way travel time) depth map of main thrust surfaces. The three thrusts in the SE were generally mapped on $2 \mathrm{D}$ seismic, and show a simple S/SE dipping trend. In the NW, thrust geometry is more complex. For more details see text 
However, as developed on an elevated basement high (Fig. 2B), Pannonian formations are very thin there. Also, the $2 \mathrm{D}$ seismic coverage and quality is less than perfect. Thus, we assume that the Adony Basin detachment zone acted as a buffer zone for shallow strike-slip deformation, but the fault zone continues to the $\mathrm{SW}$, even though its continuity is lost for technical/geophysical reasons.

\section{Deep continuation of faults}

Strike-slip shear should have affected deeper crustal levels. So, the question arises whether shallow faults can be directly continued at depth. It seems that the fault zones traced near the basin margins do not continue on trend towards depth. In the 3D covered northern margin it is quite clear that the shallower faults do not continue beneath the detachment. In the east, Fig. 7 shows a more deeply propagating master fault, but other sections (Figs 4, 10 and also the southwestern margin in Fig. 7) show shallower faults detaching at the level of the salt, and no direct connection is seen with the suspected deep structures. We suggest that strike-slip shear in the Pannonian was accommodated by a set of reactivated earlier faults (often thrusts) and not by through-going steep and deep faults. Shallow and deep fault systems are coupled at the detachment horizon.

\section{Pre-Pannonian flexural basin}

When the effects of Pannonian pull-apart basin formation are restored (Fig. 10), a different basin geometry emerges. This pre-Pannonian basin was possibly generated by thrusts, rather than by strike-slip or normal faults. In this sense, it can be regarded as a flexural basin.

\section{Master thrusts}

Thrusts and reverse faults have a very important role in the early tectonic evolution of the basin. The southern margin of the Pannonian-age basin is formed by two (or possibly three) major thrust ramps mapped in 2D seismic (Figs 4 and 9). Seismic resolution did not allow to adequately interpret their hinterland flats. On most sections continuous reflectors of pre-Pannonian Miocene and most likely also Oligocene strata can be followed below these thrusts. The offset is at least 1600-1700 m along the lower thrust, and equal, or probably even larger on the upper one. A third, deepest ramp is assumed below these, although it is not adequately imaged.

No well has reached the pre-Cenozoic basement on the southern high yet. The nearest deep well to the south is at Dunaújváros (Fig. 2B, C), which reached Tiszatype basement rocks. This well, however, is in another structural position (Fig. 2) on a high south of the investigated basin. So, it is not clear if the Pannonian basin's southern shoulder consists of rocks derived from the Tisza Unit or the Mid- 
Hungarian Unit, however, the latter option is more likely (see also Haas et al. 2010).

On the northern side of the basin (within 3D seismic coverage) a large thrust flat and its NW dipping ramp was mapped in more detail. The Triassic Hauptdolomit of the Transdanubian Range (encountered in well A) is thrust upon a continuous package of reflections of likely Lower Miocene and/or Upper Palaeogene age. By tracing the bright and continuous reflections below the reflection-poor Triassic, at least $7-8 \mathrm{~km}$ sub-horizontal displacement was determined. The interpretation of the lower ramp is somewhat uncertain (Figs 4 and 8), as the seismic signal/noise ratio becomes rather low in that depth.

Another thrust ramp was mapped below the one mentioned above (Figs 4, 8 and 9), but its displacement can only be estimated to be in the range of 500-1000 $\mathrm{m}$.

\section{Age of thrusting}

The fronts of thrusts on the northwestern side culminate just below the bottom of well A, significantly elevating and thinning pre-Pannonian formations (Fig. 6). The age of this frontal thrusting is not totally clear. This is mainly due to the lack of wells. On the northwestern side, on the basis of correlation with wells B and C (Fig. 2D), reflections that onlap on the high at well A (Fig. 8) are between Karpatian and Sarmatian, thus also constraining the age of the high between 17 $\mathrm{Ma}$ and $12 \mathrm{Ma}$. Heavy faulting around these wells precluded more detailed evaluation. However, as non-salt-bearing Sarmatian deposits are thin, we argue for a Karpatian-Badenian age. This, however, is just the age of the upper, relatively steep thrust ramp. Taking ramp dip as a rough estimate for tectonic transport direction, southeastern vergence is assumed on the northwestern side.

The timing of the main thrust event is less clear. Excluding the possibility of Cretaceous nappe stacking (see later), the age of thrusting is determined by the age of footwall deposits to the main thrust flat. These formations have not yet been drilled in the deep basin, so their age remains unconstrained, but younger than Eocene. It is possible that the whole basin sequence is Miocene in age, but it is very likely that at least the lowermost formations are Oligocene. This age assignment is corroborated by the almost total lack of Oligocene deposits at the frontal part of the hanging wall (Figs 4, 8) and also by studies in the continuation of the Mid-Hungarian Shear Zone in both directions: Csontos et al. (2005) in Somogy to the SE, and Palotai and Csontos (2010) at Tóalmás to the NE (Fig. 2B).

Because the dip of the lower thrust ramp is rather uncertain, we can only suspect an eastern transport direction from its western dip (Fig. 9) during the first thrusting phase. Exact time constraints are also lacking for the southern side of the basin. However, we can assume that the main thrust activity time span was similar to that in the northwest. 


\section{Backthrusting and transpression}

A number of backthrust surfaces (mainly at the southwestern part of the main thrust front on the northwestern side of the basin) call for a deep-seated strikeslip pop-up interpretation of the structure. However, the similar reflection characteristics, and mainly the continuity of reflections in the basin and below the empty zone of Triassic reflection on its northwestern side, indicate the existence of flat allochthonous sheets. It is likely that the rise of this structure (Fig. 10) involved transpressional movements, as the front of the main thrust is relatively steep (Figs 8, 9) and a number of backthrust surfaces were observed (Fig. 10). The age for this event is Middle Miocene, most likely Karpatian-Badenian (see above).

\section{Section restoration}

In order to review the structural evolution, we restored a section across the basin using the Move2011.2 software. Attempts to fully restore a 3D model of the area failed due to the complexity of the basin and the incompleteness of the model in the area with 2D seismic coverage. Restoration was completed at a NWSE oriented section (Fig. 10). Although we also tried to restore other, parallel sections across the basin, and yet others along the basin axis, the validation of these failed because of trying to balance strike-slip movements being out of the plane of restoration. This also means that the presented restoration workflow (Fig. 10) has to be used with caution, and it should be regarded as only a lower estimate on deformation. Nevertheless, it presents a useful overview of the tectonic evolution of the basin.

Restoration involved the sequential retro-deformation of the youngest formation in each step to its depositional (horizontal or sub-horizontal) palaeogeometry by un-faulting and unfolding, and the decompaction of this restored surface to rebounce its substrata. Fault movements were modelled mostly by the fault parallel flow algorithm (Kane et al. 1997; Egan et al. 1999), but occasionally also by trishear (Erslev 1991) and simple shear. Decompaction (Sclater and Christie 1980) parameters were as follows: initial porosity of 0.4 for all horizons; depth coefficient of 0.4 for the basin infill, 0 for the basement units, taken as uncompressible. Without actual porosity-depth data in the study area wells, these admittedly rough parameters were taken from other MOL studies in the Pannonian Basin, but yielded appropriate results. Airy-type isostasy was also taken into account during decompaction.

The basin evolution along the chosen section can be summarized as follows (Fig. 10). In a pre-deformation state, the ALCAPA and Mid-Hungarian Unit basement blocks were juxtaposed to each other, with the lowermost continuous reflection in the basin taken as the basement formation in between. Without direct age constraints, the first shortening phase - resulting in a nappe on the northwestern side and probably two thrusts in the SW - occurred in the Late Oligocene or Early Miocene. Convergent thrusting continued throughout the 


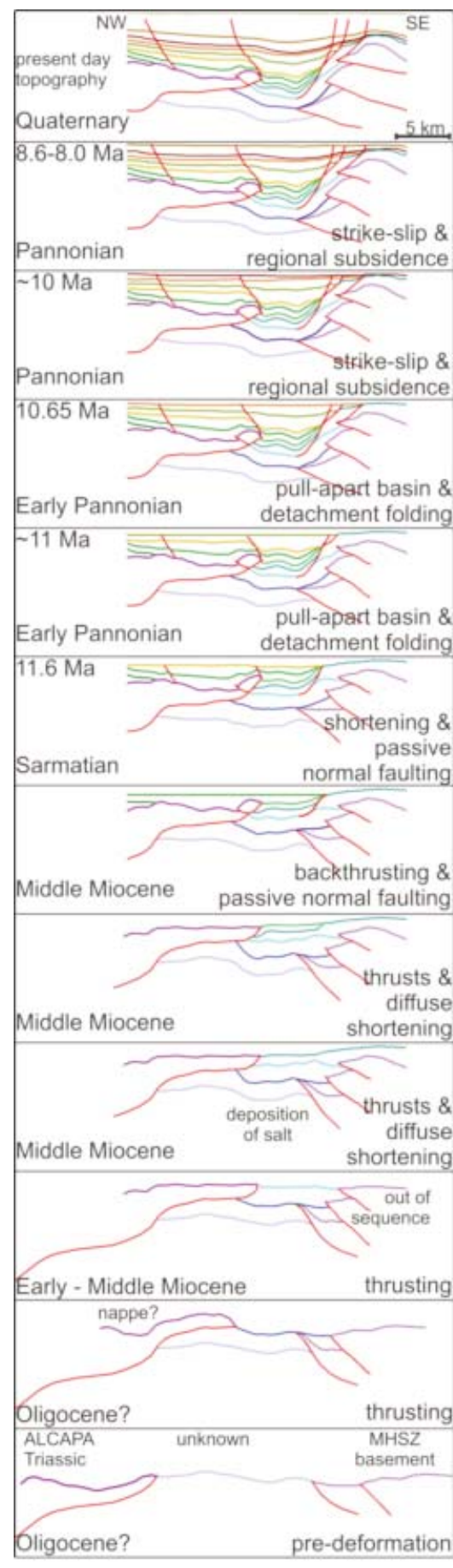

Fig. 10

Restored section across the basin. For location see Fig. 2D. Detailed interpretation in the text

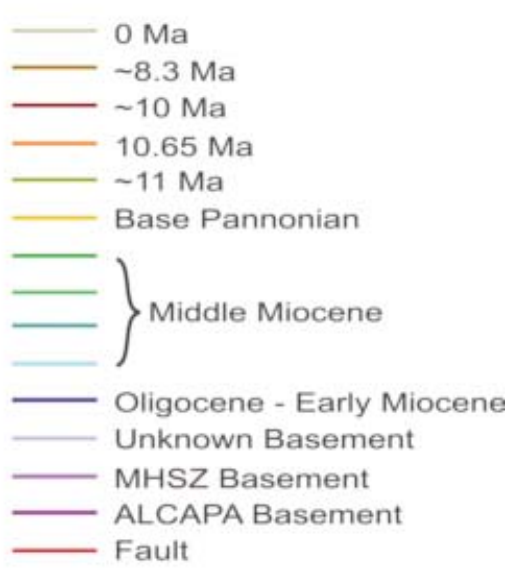

Central European Geology 55, 2012 
Early and Middle Miocene, with the majority of shortening occurring in the earlier times. On the southeastern side, three thrusts could be distinguished, with at least one stage of out of sequence thrusting. Between advancing thrusts on both sides, the syn-tectonic basin infill reached a significant thickness. Probably in the Badenian, a passive normal fault was initiated, as precursor of salt tectonics, along the front of the advancing southeastern thrusts. This fault detached on the suspected salt layer.

Backthrusting of probably Badenian age occurred at the front of the ALCAPA nappe, creating the elevated bulge along the basin margin. Shortening continued in the Sarmatian, with gravity-driven (passive) normal faults on both basin margins detaching on the salt. This resulted in the onset of detachment folding.

The change from convergent thrust-related tectonics to strike-slip happened around the very beginning of Pannonian. In the earliest Pannonian, the most pronounced subsidence of the pull-apart basin occurred, with its sidewall faults detaching on the salt, thus creating a roll-over anticline along the section. Regional subsidence and strike-slip movement continued throughout the Pannonian, with the depocenter remaining at a constant location all the time.

\section{Discussion}

\section{Thrusts and alternatives}

Triassic dolomites reached by well A show a reflection-poor character. Below them, relatively continuous, medium to high amplitude reflections are seen (Figs $4,8,11)$. They were initially interpreted as Lower to Middle Triassic or Permian deposits. However, our analysis of seismic sections throughout ALCAPA has not revealed the seismic character of these formations, probably due to the shading effect of Upper Triassic dolomites and/or limestones. The appearance of clear reflections below them and the discordant geometry of the two reflection-units (Fig. 11) suggests a most likely tectonic contact.

A possible explanation would be that these reflections are from Cretaceous strata. This would mean that the Triassic above them forms a Cretaceous (or slightly younger) thrust sheet. This model is supported by a well near Csôvár to the NE of Budapest, where different age Cretaceous strata (including Senonian) were sandwiched between Triassic carbonates (Haas et al. 1997; Benkő and Fodor 2002).

A major question regarding the allochthonous thrust sheet(s) on the northwestern side of the basin is if the footwall reflections are indeed continuous or not. Unfortunately, no depth converted seismic based upon our interpretation exists yet. Dolomites have a much higher seismic velocity than younger siliciclastic deposits. This results in the velocity pull-up and apparent thinning of reflectors below the dolomites. Thus, the real thickness of strata below the dolomite might not be significantly lower than of those in the basin proper as seen on time sections. There is a pronounced tepee-like structure at the northwestern 
basin margin (Figs 4 and 8) that, at a superficial view, calls for interpretation as a deep-seated and steep fault zone that totally separates the reflections on its sides. In most cases, however, reflections can be traced across this structure (Figs 4 and 8 ). Even vertical amplitude variation patterns captured on correlation polygons suggest that - apart from apparent thinning of reflectors on the northwestern side - strata can be correlated through this zone. The tepee structure might be

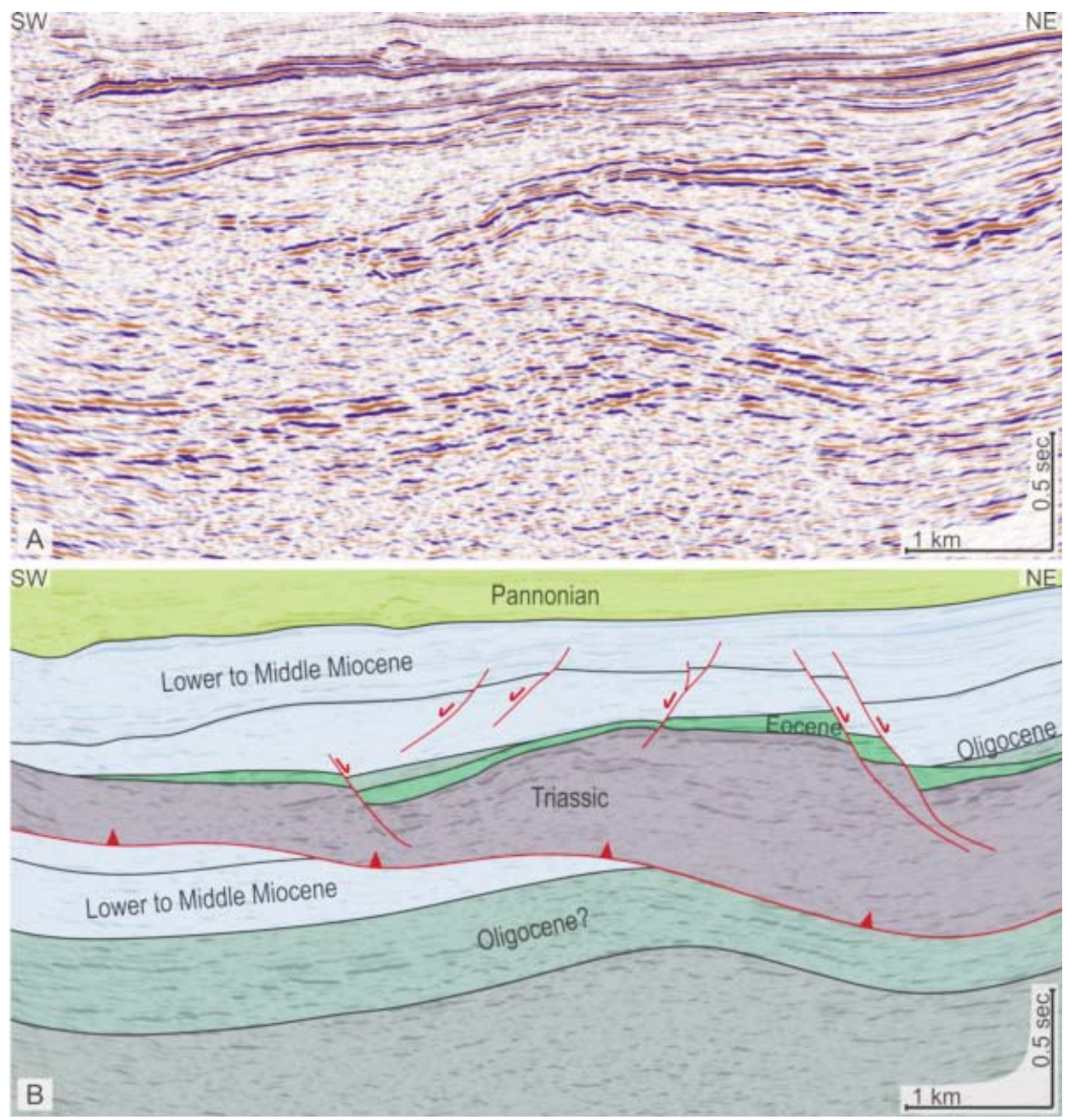

Fig. 11

Uninterpreted (A) and interpreted (B) seismic section on the northwestern side of the pull-apart basin. For location see Fig. 2D. Continuous high amplitude reflections in the lower part are regarded as Oligo-Miocene sediments being overthrust by Triassic dolomites with a reflection-poor character. Normal faults in the Triassic do not reach below the nappe boundary 
partly due to velocity distortion effects at the contact zone between rocks of greatly different seismic velocities.

Due to the lack of wells reaching this level, we cannot totally exclude alternatives, but we argue that these sub-Triassic reflections come from young, i.e. Oligocene and Miocene sediments (Fig. 11). This means that the northwestern margin of the pull-apart basin is in fact the front of a nappe composed of Triassic dolomites.

The detachment depth of the described thrusts (especially the ones on the southern side of the basin, within $2 \mathrm{D}$ seismic coverage) is not totally clear. Seismic interpretation (Figs 4, 8) and section restoration (Fig. 11) nevertheless show a generally thin-skinned tectonic style. No clear data exist on the stratigraphic level of detachment, Triassic marls of the Transdanubian Range being a preferred candidate.

\section{Origin and deformation of salt}

Apart from well A (Figs 2D, 8), no salt is known in any borehole nearby, so, further studies will be needed to define the spatial and temporal extents and sedimentary environment of the salt basin. We prefer a sedimentary origin of the salt, with tectonically induced thickness variations. If this is the case, then the age of salt is Badenian (if we accept conclusion of the report), or Badenian and/or Sarmatian (if sporomorph ages are taken into account). In this sense, the salt unit of the Adony Basin cannot be regarded as allochtonous, despite the described deformation of this unit.

A likely analogue of evaporite formations is the Sarmatian Zsámbék basin (Jámbor 1967, 1969; Boda 1974; Görög 1992; Cornée et al. 2009; Fig. 2B) hosting some thin gypsum and anhydrite layers. Its extents to the SE are not clear, and the observed thickness is far less than in well A.

The Badenian of the central part of the Pannonian Basin is generally not evaporitic, however, thick salt deposits of this age are known in the Transylvanian Basin (Krézsek and Filipescu 2005; Krézsek et al. 2010, Fig. 2A). These formations - and other, similar age evaporites common in the Central Paratethys - are of deep marine origin (Báldi 2006).

Another potential source of evaporites could be the Carnian of the Transdanubian Range (Fig. 2B, C), where salty layers locally interfinger with shales at some localities (Haas and Budai 1999). This would mean that the almost $200 \mathrm{~m}$ thick halite sequence at the northwestern basin margin would form an allochthonous salt sheet. Without further seismic evidence of this type of salt tectonics, this solution seems unlikely.

The detachment horizons in the basin are all within the well reflecting suite, easily distinguished from the seismic (pre-Tertiary) basement. No salt necks, subvertical welds etc. seem to connect the basement and the ductile units within the basin. This also excludes the halokinetic importance of Triassic evaporites. 
The salt-cored, non-cylindrical folds (domes and basins) are not arranged in an en echelon manner (Fig. 6F, G, H), precluding the possibility of them being wrench folds as described by Smit et al. (2008). With the overburden of the salt being thickest in the central part of the basin (Fig. 6F, G, H, Fig. 7), we do not see any evidence for differential loading or passive downbuilding.

The geometry of detached domes and synclines is related to the shape of the pull-apart basin, i.e. its sidewall faults. Ductile rocks on a steep, faulted margin induce gravity-driven sliding of the supra-salt units into the basin. With both the northwestern and eastern basin margins being steep, convergent sliding from both sides would create detached anticlines in the centre of the basin (Fig. 10). A similar, gravity-driven process is suggested for the southwestern part of the basin (Fig. 7), although this margin, with a ramp-flat geometry of the salt unit, is less steep.

\section{Pull-apart basin characteristics and analogues}

On the base Pannonian level, the length of the lazy-S-shaped (Mann et al. 1983) pull-apart basin at its longest diagonal is $12.4 \mathrm{~km}$, its (perpendicular) maximal width being $4.8 \mathrm{~km}$. Thus, the length/width ratio of the basin is 2.58 . This value is somewhat below the average of pull-apart basins (Aydin and Nur 1982). Lacking depth-converted seismic data, the depth of the basin can only be approximated. The majority of strike-slip deformation occurred from the earliest Pannonian until the Pa3 level (see above). Taking the salt detachment horizon as the basin floor, the thickness up to the basin margin Pa3 level is around $2.5 \mathrm{~km}$.

The basin shows a pronounced asymmetry. The infill near the southeastern margin (immediately above the detachment zone) is thinner than at the northwestern margin (placing the depocentre closer to the northwestern margin), whereas salt is extruded below towards the southeast (Fig. 4). We attribute this to the following: the northwestern margin accommodated the majority of displacement, resulting in more active marginal gravity sliding than on the opposite side. Welding and extrusion of the salt sequence towards the southeastern side of the basin resulted in the asymmetrical structure of the basin in cross-sections. Somewhat similar asymmetric pull-apart basins related to differing slip rates on basin margins were modelled by Rahe et al. (1998).

As the southern termination and the whole southeastern margin of the Adony Basin lies outside the 3D seismic coverage (Fig. 6), the exact geometry here cannot be determined. The overall map view shape of the basin, however, is not very much different from the $30^{\circ}$ releasing sidestep pull-apart model of Dooley and McClay (1997).

Similar lazy-S-shaped pull-apart basins are quite widespread (for a summary see Mann 2007) and indicate an early intermediate stage of basin development. Details of fault geometry, however, differ significantly from the more common pull-apart basin style of deep seated, steep basin sidewall faults. We attribute 
these differences to the local occurrence of salt in the study area. However, as the thickness of the Adony salt sequence is much less than that in the Dead Sea Basin (Smit et al. 2008), salt-related deformation is much less intense: the Adony Basin lacks diapirs, salt ridges and other high mobility salt features. A significant difference to other strike-slip basins in a similar evolutionary stage (e.g. Reijs and McClay 2003; Cembrano et al. 2005), as well as analogue models on pull-aparts (e.g. Dooley and McClay 1997; Wu et al. 2009) is the lack of cross-basin shortcut faults. In our view, this peculiarity comes from the presence of salt in the Adony area, at least partially decoupling the basin infill and concentrating brittle deformation to the basin margins.

Being a reactivated thrust zone largely influenced by earlier structures, at first it is not clear whether the Adony pull-apart basin developed in a pure strike-slip or in a transtensional regime. The lack of pull-aparts along the long linear segment of the Tóalmás Zone NE of the study area (Palotai and Csontos 2010) suggests a pure strike-slip regime. Also, the mapped basin geometry is closer to the pure strike-slip model of $\mathrm{Wu}$ et al. (2009) than their transtensional version. This idea is corroborated by the Early Pannonian activity of east-west striking thrust segments on basin margins (see above, Fig. $6 \mathrm{H}$ ) indicating ongoing shortening within a strike-slip regime.

\section{Regional correlation}

The Mid-Hungarian Shear Zone experienced large scale strike-slip (Fodor 2010) and thrust (Csontos and Nagymarosy 1998) movements. While Fodor (2010) emphasized the importance of strike-slip, we suggest another scenario. Our results are in accordance with the concepts of Csontos et al. (2005) and Palotai and Csontos (2010) in Somogy and at Tóalmás, respectively (Fig. 2B). These studies show that in the central part of the Mid-Hungarian Shear Zone, shortening features were more important in the Oligocene to Early Miocene structural evolution. The large scale thrust structures mapped in the 3D seismic volume support the idea of significant shortening in this time interval. Although we cannot totally exclude the strike-slip alternative, the nappe interpretation is much more likely here (see above).

Our novel distinction between the Oligocene to Lower/Middle Miocene thrust basin and the Pannonian pull-apart basin also means that a simple continuous pre-Pannonian Tertiary strike-slip model cannot be applied to the Adony Basin area and its surroundings in the Oligocene and Early Miocene.

Demonstrating both NW and SE verging thrusts in the Oligocene/Early Miocene, our interpretation is significantly different from that of Csontos and Nagymarosy (1998). Their SE verging Palaeogene thrusts appeared all within the Mid-Hungarian Unit, while in our view the tectonic transport direction in this unit near the Adony Basin is opposite to this. 
Convergent thrusts in the Mid-Hungarian Shear Zone have been known from Somogy (Fig. 2B), to the south of Lake Balaton (Balla et al. 1987; Csontos et al. 2005). Thus, the basin type described in our study is not completely new for the Pannonian Basin, despite the lack of major proven imbricates in Somogy. Due to the small areal coverage of 3D seismic, the extent of the Adony thrust basin is unknown so far, but might be significantly larger than mapped in our study.

With the largest thrust offset in the Bugyi High area (Csontos and Nagymarosy 1998, Fig. 2B, C), and also northeast of it (Fodor et al. 2005; Palotai and Csontos 2010) occurring in the Late Oligocene, we suspect that at least the deepest footwall deposits in the Adony Basin are Oligocene in age, inferring a similar age for the main thrusting event. Drilling exploration would be needed to precisely determine the depth of the Oligocene/Miocene boundary within the basin. The steep frontal part of the SE verging thrust (Fig. 9) and related backthrusts were active in the Middle Miocene (see section restoration results, Fig. 10). This means that transpression might have become more important at this time interval. The strike-slip duplex concept on the map of Haas et al. (2010), and also that of Fodor (2010) may thus be valid mainly for the (Early to?) Middle Miocene.

Transpressional orogens host the combination of thrusts and strike slip faults (Cunningham 2005, 2007). Having described both thrusts (Csontos and Nagymarosy 1998; Csontos et al. 2005; Palotai and Csontos 2010; and this study) and strike-slip faults (Balla and Dudko 1989; Fodor et al. 1999; Ruszkiczay-Rüdiger et al. 2007; Fodor 2010; Haas et al. 2010), the Oligocene to Middle Miocene MidHungarian Shear Zone can be regarded as a transpressional orogen, with varying significance of shortening and strike-slip in time. Whereas in the Oligocene and Early Miocene thrusting is regarded as dominant, in the Middle Miocene the strike-slip component of the deformation might have become more important. Limited age data should be kept in mind when describing timing of events.

The relative importance of strike-slip and thrust faults in a transpressional orogen is determined by the orientation of structures to the regional SHmax, resulting in complex strain partitioning patterns (Jamison 1991; Teyssier et al. 1995; Fossen and Tikoff 1998; Cunningham 2007). The evolution from a strike-slip dominated orogen to a thrust dominated one arises from vertical axis rotations (Cunningham 2007). In contrast to the Mongolian mountain belts (Cunningham $2005,2007)$, which seem to rotate in regionally consistent blocks, we argue that the Mid-Hungarian Shear Zone behaved in a more complex manner. Palaeomagnetic studies suggested the rotational disintegration of ALCAPA during the Miocene (Márton and Fodor 2003) into more or less separate subunits. Vertical axis rotations within the late Palaeogene Mid-Hungarian Shear Zone between the Bugyi High and the Zagyva River (Fig. 2C) have already been proposed by Palotai and Csontos (2010). The small size of rotating blocks may reflect a relatively shallow detachment depth. Indeed, seismic interpretation (Figs 4, 8) and restoration (Fig. 10) results show that the Oligo-Miocene tectonic style was thinskinned. If relatively thin and small blocks rotate more or less independently in a 
shear zone, significant local variations in strain patterns develop. We think that the Oligocene to Early Miocene thrusts of Adony Basin were part of a purely compressional zone of this regionally transpressional orogen. In this sense, the studied flexural basin could be regarded as a ramp basin sensu Cunningham (2005), although this terminology has generally been applied to basins related to transpressional, i.e. strike-slip thrust ramps. It is to be noted, however, that the Oligo-Miocene thrusts NE of the Bugyi High also show significant offsets (Palotai and Csontos 2010). The same can be applied to the Somogy area (Csontos et al. 2005). This means that shortening across the Mid-Hungarian Shear Zone was more important than strike-slip, putting it into the pure shear dominated type of transpression (Teyssier et al. 1995).

The sinistral character, as well as the neotectonic activity of the Tóalmás Zone has been clarified by Fodor et al. (2005) and Ruszkiczay-Rüdiger et al. (2007). This phase is related to the ongoing eastward subduction at the outer, Carpathian front of the Tisza unit, with ALCAPA already being stabilized (Horváth 2007; Fodor 2010). Although the amount of Pannonian sinistral strike-slip has yet to be determined, only a precursor of this well defined strike-slip fault zone, probably with much different kinematics, can be regarded as a Balaton-type facies boundary fault. This means that although the Tóalmás Zone, as a Pannonian age feature, lies in the apparent continuation of the Balaton Line, no direct geometric link needs to be assumed between them. The apparent lack of continuation of Pannonian age strike-slip faults on the 2D seismic dataset SW of the Adony pullapart basin means that strain might be partitioned between the formations above and below the salt. Although we cannot exclude that the shallow strike-slip zone ends at Adony, deep structures necessarily continue to the SW (Fig. 2B, C). Fodor (2010) suggested that the Tóalmás Zone initiated as part of the Mid-Hungarian Shear Zone as a large scale dextral strike-slip fault, that was reactivated as a sinistral, mainly transtensional fault in the Pannonian, or slightly earlier. While we agree on the sinistral phase, the thrusts described in this study show that the Oligocene to Early/Middle Miocene kinematics of the Mid-Hungarian Shear Zone was mostly compressional, with some likely transpressional episodes in the Middle Miocene (Fig. 10). The Adony Basin could be interpreted as a restraining stepover of a dextral strike-slip zone (see Fig. 2C), reactivated in the Pannonian as a pull-apart once slip reversed on the shear zone. However, the studies of Csontos et al. (2005) in Somogy to the SE, and of Palotai and Csontos (2010) at Tóalmás to the NE (Fig. 2B) both show that even on the straight segments of the Oligocene to Early Miocene Mid-Hungarian Shear Zone, compressional thrusting and folding was the primary style of deformation.

Based upon palaeomagnetic data (Márton 1985; Márton and Márton 1989), the opposite rotation of the ALCAPA and Tisza units can be inferred (Balla 1984; Csontos and Vörös 2004). Two vertical axis rotation events were identified by Márton and Fodor (2003): a major one between 18-17 Ma, later refined by Márton et al. (2007) and Fodor (2010) as 18.5-17.5 Ma, i.e. in the Ottnangian and Karpatian 
(Fig. 3), and a second, smaller one between 16-14.5 Ma (Márton and Fodor 2003) or 15-14 Ma (Fodor 2010), i.e. in the Badenian. Linking rotation to the convergence between ALCAPA and Tisza, and the intermittent deformation zone, compressional tectonics is inferred within the Mid-Hungarian Shear Zone in these time intervals.

\section{Conclusions}

The characteristics and formation mechanism of the Adony Basin within the Mid-Hungarian Shear Zone were clarified. Although at a superficial view, this basin could have been regarded as a simple pull-apart, the detailed analysis of 3D seismic data enabled us to provide a more complex genetic model.

During the Late Oligocene and Early Miocene, a flexural basin was formed between a SE verging ALCAPA nappe in the NW and NW verging Dinaric thrusts in the SE in the central part of the Mid-Hungarian Shear Zone. The total rate of NW-SE oriented shortening was in the range of $13 \mathrm{~km}$ until the Sarmatian. Although we argue for the existence of the ALCAPA nappe, the lack of wells reaching the suspected autochthonous units allows for alternative interpretations. Compression, with an increasing transpressional component, continued in the Middle Miocene.

The deposition of salt in the region during the Badenian (and/or Sarmatian?) acted as a detachment surface for later tectonic processes. The extent of the salt basin is unknown, but is assumed to be a local feature.

In the earliest Pannonian, a sinistral pull-apart basin was created above the earlier flexural basin. Strike-slip faults in the Upper Miocene strata were partly detached from the basement. Gravity-driven sliding on the steep flanks of the basin margin resulted in detachment folding in the basin. The most intense strike-slip deformation of this basin occurred in the early Pannonian, but the tectonic activity along at least the northwestern fault zone continued throughout the Late Miocene.

\section{Acknowledgements}

The authors thank the generous support of MOL for providing the dataset and giving their permission to publish this study. Midland Valley and IHS are gratefully acknowledged for providing software background. Discussions with A. Milánkovich, L. Fodor and J. Haas, and the technical support of J. Pálfy and A. Kővári improved the manuscript. The comments of three anonymous reviewers helped improve clarity and presentation. The study was supported by the Hungarian Scientific Research Fund (OTKA) grant 81530. 


\section{References}

Árkai, P., K. Balogh, I. Dunkl 1995: Timing of low-temperature metamorphism and cooling of the Palaeozoic and Mesozoic formations of the Bükkium, innermost West Carpathians, Hungary. Geol. Rundschau, 84, pp. 334-344.

Aydin, A., A. Nur 1982: Evolution of pull-apart basins and their scale independence. - Tectonics, 1, pp. 91-105.

Báldi, K. 2006: Paleoceanography and climate of the Badenian (Middle Miocene, 16.4-13.0 Ma) in the Central Paratethys based on foraminifera and stable isotope $\left(\delta^{18} \mathrm{O}\right.$ and $\left.\delta^{13} \mathrm{C}\right)$ evidence. - Int. J. Earth Sci. (Geol. Rundsch.), 95, pp. 119-142.

Báldi, T. 1983: Magyarországi oligocén és alsómiocén formációk (Oligocene and Lower Miocene formations in Hungary). - Akadémiai Kiadó, Budapest, 293 p.

Báldi, T., M. Báldi-Beke 1985: The evolution of the Hungarian Paleogene basins. - Acta Geologica Hungarica, 28/1-2, pp. 5-28.

Balla, Z. 1984: The Carpathian loop and the Pannonian basin: a kinematic analysis. - Geophysical Transactions, 30/4, pp. 313-353.

Balla, Z. 1999: Lineaments of Hungary. - MÁFI Évi Jelentése, 1992-93/II, pp. 15-20.

Balla, Z., A. Dudko 1989: Large-scale Tertiary strike-slip displacements recorded in the structure of the Transdanubian range. - Geophysical Transactions, 35, pp. 3-63.

Balla, Z., M. R. Tátrai, A. Dudko 1987: A Közép-Dunántúl fiatal tektonikája földtani és geofizikai adatok alapján (Young tectonics of Transdanubia based on geological and geophysical data). Annual Rep. of MáELGI Geophysical Institute from 1986, pp. 74-94.

Benkő K., L. Fodor 2002: Csővár környékének szerkezetföldtana (Structural geology of the Csôvár region). - Földtani Közlöny, 132, pp. 223-246.

Bérczi-Makk, A. 1978: Tengeri felsőperm üledékek Budapesttől DK-re a Sári-2. sz. szénhidrogénkutató fúrásban (Marine Upper Permian sediments SE of Budapest in the Sári-2 hydrocarbon exploration well). - Földtani Közlöny, 108, pp. 313-327.

Boda, J. 1974: A magyarországi szarmata emelet rétegtana (Sarmatian stratigraphy in Hungary). Földtani Közlöny, 104, pp. 249-260.

Buda, Gy. 1992: Tectonic settings of the Variscan granitoids occurring in Hungary and some other surrounding areas. - Terra Nova Abstr. Suppl., 2, p. 10.

Cembrano, J., G. González, G. Arancibia, I. Ahumada, V. Olivares, V. Herrera 2005: Fault zone development and strain partitioning in an extensional strike-slip duplex: A case study from the Mesozoic Atacama fault system, Northern Chile. - Tectonophysics, 400, pp. 105-125.

Channel, J.E.T., F. Horváth 1976: The African (Adriatic) Promontory as a paleogeographical premise for Alpine orogeny and plate movements in the Carpatho-Balkan Region. - Tectonophysics, 35, pp. 71-101.

Cornée, J-J., P. Moisette, J-P. Saint Martin, M. Kázmér, E. Tóth, Á. Görög, A. Dulai, P. Müller 2009: Marine carbonate systems in the Sarmatian (Middle Miocene) of the Central Paratethys: the Zsámbék Basin of Hungary. - Sedimentology, 56/6, pp. 1728-1750.

Cserepes-Meszéna, B. 1986: Petrography of the crystalline basement of the Danube-Tisza interfluve (Hungary). - Acta Geologica Hungarica, 29/3-4, pp. 321-340.

Csontos, L. 1995: Tertiary tectonic evolution of the Intra-Carpathian area: a review. - Acta Vulcanologica, 7/2, pp. 1-13.

Csontos, L., A. Nagymarosy 1998: The Mid-Hungarian line: a zone of repeated tectonic inversions. Tectonophysics, 297, pp. 51-71.

Csontos, L., A. Vörös 2004: Mesozoic plate tectonic reconstruction of the Carpathian region. Palaeogeography, Palaeoclimatology, Palaeoecology, 210, pp. 1-56.

Csontos, L., A. Nagymarosy, F. Horváth, M. Kovác 1992: Cenozoic evolution of the Intra-Carpathian area: a model. - Tectonophysics, 208, pp. 221-241.

Csontos, L., Á. Magyari, B. Van Vliet-Lanoe, B. Musitz 2005: Neotectonics of the Somogy Hills (Part II): evidence from seismic sections. - Tectonophysics, 410, pp. 63-80. 
Cunningham, W.D. 2005: Active intracontinental transpressional mountain building in the Mongolian Altai: Defining a new class of orogen. - Earth and Planetary Science Letters, 240, pp. 436-444.

Cunningham, W.D. 2007: Structural and topographic characteristics of restraining bend mountain ranges of the Altai, Gobi Altai and easternmost Tien Shan. - In: Cunningham, W.D., P. Mann (Eds): Tectonics of strike-slip restraining and releasing bends. Geological Society, London, Special Publication, 290, pp. 219-237.

Dooley, T., K. McClay 1997: Analog modeling of pull-apart basins. - AAPG Bulletin, 81/11, pp. 1804-1826.

Drobne, K. 1977: Alvéolines Paléogenes de la Slovénie et de l'Istrie (Paleogene Alveolines from Slovenia and Istria). - Schweiz. Pal. Abh. 99, pp. 1-174.

Dudko, A. 2004: Szerkezet (Structure). - In: Gyalog, L., I. Horváth (Eds): A Velencei-hegység és a Balatonfő földtana. Magyarázó a Velencei-hegység földtani térképéhez (1:25000) és a Balatonfô-Velencei-hegység mélyföldtani térképéhez (1:100000) (Geology of the Velence Hills and the Balatonfő. Explanations to geological maps in the region). - Geological Institute of Hungary, $316 \mathrm{p}$.

Egan, S.S., S. Kane, T.S. Buddin, G.D. Williams, D. Hodgetts 1999: Computer modelling and visualisation of the structural deformation caused by movement along geological faults. Computers \& Geosciences, 25/3, pp. 283-297.

Erslev, E.A. 1991: Trishear fault-propagation folding. - Geology, 19/6, pp. 617-620.

Faupl, P., G. Császár, M. Mišik 1997: Cretaceous and Palaeogene sedimentary evolution in the Eastern Alps, Western Carpathians and the North Pannonian region: An overview. - Acta Geologica Hungarica, 40/3, pp. 273-305.

Flügel, H.W. 1975: Einige Probleme des Varistikums von Neo-Europa (Some problems of the Varisticum of Neo-Europe). - Geol. Rundsch., 64/1, pp. 1-62.

Fodor, L. 2010: Mezozoos-kainozoos feszültségmező́k és törésrendszerek a Pannon-medence ÉNy-i részén - módszertan és szerkezeti elemzés (Mesozoic-Cenozoic stress fields and fault systems in the northwestern part of the Pannonian Basin). - Doctoral thesis, Hungarian Academy of Sciences, $167 \mathrm{p}$.

Fodor, L., Á. Magyari, M. Kázmér, A. Fogarasi 1992: Gravity-flow dominated sedimentation on the Buda paleoslope (Hungary): Record of Late Eocene continental escape of the Bakony unit. Geol. Rundsch., 81/3, pp. 695-716.

Fodor, L., L. Csontos, G. Bada, I. Gyôrfi, L. Benkovics 1999: Cenozoic tectonic evolution of the Pannonian basin system and neighbouring orogens: a new synthesis of paleostress data. - In: Durand, B., L. Jolivet, F. Horváth, M. Séranne (Eds): The Mediterranean basins: Cenozoic extension within the Alpine orogen. Geological Society, London, Special Publications, 156, pp. 295-334.

Fodor, L., G. Bada, G. Csillag, F. Horváth, Zs. Ruszkiczay-Rüdiger, K. Palotás, F. Síkhegyi, G. Tímár, S. Cloetingh, F. Horváth 2005: An outline of neotectonic structures and morphotectonics of the western and central Pannonian Basin. - Tectonophysics, 410, pp. 15-41.

Fossen, H., B. Tikoff 1998: Extended models of transpression and transtension, and application to tectonic settings. - In: Holdsworth, R.E., R.A. Strachan, J.F. Dewey (Eds): Continental Transpressional and Transtensional Tectonics. Geological Society, London, Special Publications, 135, pp. 15-33.

Fülöp, J., V. Dank (Eds) 1987: Pre-Cenozoic geological map of Hungary, 1:500 000. - MÁFI, Budapest.

Géczy, B. 1973: Plate tectonics and paleogeography in the East-Mediterranean Mesozoic. - Acta Geologica Hungarica, 17, pp. 421-428.

Géczy, B. 1984: Provincialism of Jurassic ammonites: examples from Hungarian faunas. - Acta Geologica Hungarica, 27/3-4, pp. 379-389.

Görög, Á. 1992: Sarmatian foraminifera of the Zsámbék Basin, Hungary. - Ann. Univ. Sci. Budap. Sect. Geol., 29, pp. 31-153. 
Gulyás, Á. 2005: Gravity Bouguer Anomaly Map of Hungary 1:500000. - Eötvös Loránd Geophysical Institute of Hungary.

Haas, J. 1999: Late Cretaceous isolated platform evolution in the Bakony Mountains (Hungary). Geologica Carpathica, 50/3, pp. 241-256.

Haas, J., S. Kovács, L. Krystyn, R. Lein 1995: Significance of Late Permian-Triassic facies zones in terrane reconstructions in the Alpine-North Pannonian domain. - Tectonophysics, 242/1, pp. $19-40$.

Haas, J., T. Budai 1999: Triassic sequence stratigraphy of the Transdanubian Central Range (Hungary). - Geologica Carpathica, 50/6, pp. 459-475.

Haas, J., E. Tardi-Filácz, A. Oravecz-Scheffer, F. Góczán 1997: Cretaceous insertions in Triassic (?) dolomites at Csôvár, North Hungary. - Acta Geologica Hungarica, 40, pp. 179-196.

Haas, J., T. Budai, L. Csontos, L. Fodor, Gy. Konrád (Eds): 2010: Pre-Cenozoic basement map of Hungary 1: 500000. - Geological Institute of Hungary.

Horváth, F. 2007: A Pannon-medence geodinamikája. Eszmetörténeti tanulmány és geofizikai szintézis (Geodynamics of the Pannonian Basin. History of ideas and geophysical synthesis). Doctoral thesis, Hungarian Academy of Sciences., 238 p.

Horváth, F., E. Dombrádi 2010: A magyar tektonikai gondolkodás fejlődése a Balaton és környéke kutatásának tükrében (Evolution of Hungarian tectonics: an overview of a century of research on and around Lake Balaton). - Földtani Közlöny, 140/4, pp. 335-354.

Iacopini, D., W.H. Butler 2011: Imaging deformation in submarine thrust belts using seismic attributes. - Earth and Planetary Science Letters, 302, pp. 414-422.

Jamison, W.R. 1991: Kinematics of compressional fold development in convergent wrench terranes. -Tectonophysics, 190, pp. 209-232.

Jámbor, Á. 1967: A Budapest környéki neogén fácies- és ősföldrajzi vázlatai (Sketches on Neogene facies and palaeogeography around Budapest). - Geological Institute of Hungary.

Jámbor, Á. 1969: A Budapest környéki neogén képződmények ősföldrajzi vizsgálata

(Palaeogeographic study on the Neogene formations around Budapest). - Annu. Rep. Ungar. Geol. Inst. 1967, pp. 135-142.

Juhász, Á. 1964: Adatok a Duna-Tisza-köze É-i részének mélyföldtanához (Data on the subsurface geology of the northern part of the Danube-Tisza interfluves). - Földtani Közlöny, 94/2, pp. 84-194.

Kane, S.J., G.D. Williams, T.S. Buddin, S.S. Egan, D. Hodgetts 1997: Flexural-slip Based Restoration in 3D, A New Approach. - American Association of Petroleum Geologists Annual Convention Official Program: A58.

Kázmér, M., S. Kovács. 1985: Permian-Palaeogene palaeogeography along the eastern part of the Insubric-Periadriatic lineament system: evidence for continental escape of the Bakony-Drauzug unit. - Acta Geologica Hungarica, 28, pp. 71-84.

Kovács, I., L. Csontos, Cs. Szabó, E. Bali, Gy. Falus, K. Benedek, Z. Zajacz 2007: Paleogene-early Miocene igneous rocks and geodynamics of the Alpine-Carpathian-Pannonian-Dinaric region: An integrated approach. - In: Beccaluva, L., G. Bianchini, M. Wilson (Eds): Cenozoic Volcanism in the Mediterranean Area. Geological Society of America Special Paper, 418, pp. 93-112.

Kovács, S. 1982: Problems of the "Pannonian Median Massif", the plate tectonic concept. Contributions based on the distribution of Late Paleozoic, Early Mesozoic isopic zones. - Geol. Rundschau, 71/2, pp. 617-640.

Kovács, S., J. Haas 2010: Displaced South Alpine and Dinaridic elements in the Mid-Hungarian Zone. - Central European Geology, 53/2-3, pp. 135-164.

Kovács, S., Gy. Buda, J. Haas, K. Brezsnyánszky, Sz. Harangi 2010: Tectonostratigraphic terranes and zones juxtaposed along the Mid-Hungarian Line: their contrasting evolution and relationships. - Central European Geology, 53/2-3, pp. 165-180.

Kőrössy, L., 1981. Regional geological profiles in the Pannonian basin. - Earth Evol. Sci., 1/3-4, pp. 223-231. 
Kőrössy, L. 2004: Az észak-magyarországi paleogén medence kőolaj- és földgázkutatásának földtani eredményei (Geological results of oil and gas exploration in the North Hungarian Paleogene Basin). - Általános Földtani Szemle, 28, pp. 7-119. (In Hungarian.)

Krézsek, Cs., S. Filipescu 2005: Middle to late Miocene sequence stratigraphy of the Transylvanian Basin (Romania). - Tectonophysics, 410/1-4, pp. 437-463.

Krézsek, Cs., S. Filipescu, L. Silye, L. Matenco, H. Doust 2010: Miocene facies associations and sedimentary evolution of the Southern Transylvanian Basin (Romania): Implications for hydrocarbon exploration. - Marine and Petroleum Geology, 27, pp. 191-214.

Lakatos, L., M. Váradi, Gy. Pogácsás, A. Nagymarosy, A. Barvitz 1992: Sequence stratigraphic relations in the Zagyva trough. - Magyar Geofizika, 32, pp. 20-37.

Magyar, I. 2009: A Pannon-medence ősföldrajza és környezeti viszonyai a késő miocénben őslénytani és szeizmikus rétegtani adatok alapján (Palaeogeography and environmental conditions of the Pannonian Basin during the Late Miocene based upon palaeontological and seismic stratigraphic data). - Doctoral thesis, Hungarian Academy of Sciences, $132 \mathrm{p}$.

Mann, P. 2007: Global catalogue, classification and tectonic origins of restraining- and releasing bends on active ans ancient strike-slip fault systems. - In: Cunningham, W.D., P. Mann (Eds): Tectonics of strike-slip restraining and releasing bends. Geological Society, London, Special Publication, 290, pp. 219-237.

Mann, P., M.R. Hempton, C.B. Dwight, K. Burke 1983: Development of pull-apart basins. - Journal of Geology, 91, pp. 529-554.

Márton, E. 1985: Tectonic implications of paleomagnetic results for the Carpatho-Balkan areas. Geological Society, London, Special Publications, 17, pp. 645-654.

Márton, E., L. Fodor 2003: Tertiary paleomagnetic results and structural analysis from the Transdanubian Range (Hungary): rotational disintegration of the Alcapa unit. - Tectonophysics, 363, pp. 201-224.

Márton, E., P. Márton 1989: A compilation of paleomagnetic results from Hungary. - Geophysical Transactions, 35, pp. 117-133.

Márton, E., T. Zelenka, P. Márton 2007: Paleomagnetic correlation of Miocene pyroclastics of the Bükk Mts and their forelands. - Central European Geology, 50, pp. 47-57.

Mészáros, J. 1984: A Kárpát-medence ollós bezáródási öve (Scissor-like closure belt of the Carpathian Basin). - MÁFI Évi Jel. 1982-ről, pp. 491-500.

Nagymarosy, A. 1989: Cenozoic formations of North Hungary. - In: Császár, G. (Ed.): Excursion Guidebook, 10th Regional Meeting, Int. Assoc. Sedimentol., Hung. Geol. Inst. Budapest, pp. $37-48$.

Nagymarosy, A., M. Báldi-Beke 1993: The Szolnok unit and its probable paleogeographic position. Tectonophysics, 226, pp. 457-470.

Neubauer, F., F. Ebner, E. Wallbrecher 1995: Geological Evolution of the Internal Alps, Carpathians and of the Pannonian Basin - An Introduction. - Tectonophysics, 242, pp. 1-4.

Palotai M., L. Csontos 2010: Strike-slip reactivation of a Paleogene to Miocene fold and thrust belt along the central part of the Mid-Hungarian Shear Zone. - Geologica Carpathica, 61/6, pp. 483-493.

Piller, W.E., M. Harzhauser, O. Mandic 2007: Miocene Central Paratethys stratigraphy - current status and future directions. - Stratigraphy, 4/2-3, pp. 151-168.

Pogácsás, Gy., G. Vakarcs, A. Barvitz, L. Lakatos 1989: Postrift strike-slip faults in the Pannonian Basin and their role in the hydrocarbon accumulation. - Abstracts and Papers of the Technical Program, 34th International Geophysical Symposium 34, pp. 601-611.

Pogácsás, Gy., Gy. Juhász, J. Csizmeg, Á. Dudás, A. Milánkovich, T. Tomcsányi, B. Baracsi, B. Szabó, B. Akács, J. Mádl-Szőnyi, Sz. Simon, B. Czauner 2011: Late Miocene-Pliocene shortening, uplift and wrench tectonics dominated canyon development along the Mid-Hungarian Mobile Belt. AAPG International Conference, Milan, Italy, Abstract Volume 1072039.

Rahe, B., D.A. Ferrill, A.P. Morris 1998: Physical analog modeling of pull-apart basin evolution. Tectonophysics, 285 , pp. 21-40. 
Reijs, J., K. McClay 2003: The Salina del Fraile pull-apart basin, northwest Argentina. - Geological Society, London, Special Publication, 210, pp. 197-209.

Royden, L.H, F. Horváth, J. Rumpler, 1983: Evolution of the Pannonian basin system: 1. Tectonics. Tectonics, 2, pp. 63-90.

Ruszkiczay-Rüdiger, Zs., L.I. Fodor, E. Horváth 2007: Neotectonics and Quaternary landscape evolution of the Gödöllő Hills, Central Pannonian Basin, Hungary. - Global and Planetary Change, 58/1-4, pp. 181-196.

Schmid, S.M., D. Bernoulli, B. Fügenschuh, L. Matenco, S. Schefer, R. Schuster, M. Tischler, K. Ustaszewski 2008: The Alpine-Carpathian-Dinaridic orogenic system: correlation and evolution of tectonic units. - Swiss Journal of Geosciences, 101/1, pp. 39-183.

Sclater, J.G., P.A.F Christie 1980: Continental stretching: an explanation of the post-Mid-Cretaceous subsidence of the Central North Sea Basin. - Journal of Geophysical Research, 85/B7, pp. 3711-3739.

Smit, J., J.-P. Brun, X. Fort, S. Cloetingh, Z. Ben-Avraham 2008: Salt tectonics in pull-apart basins with application to the Dead Sea Basin. - Tectonophysics, 449/1-4, J.-pp. 1-16.

Szentgyörgyi, K. 1989: Sedimentological and faciological characteristics of the Senonian pelagic formations of the Hungarian plain. - Acta Geologica Hungarica, 32/1-2, pp. 107-116.

Szepesházy, K. 1973: Az északnyugat-Tiszántúl felső-kréta és paleogén képződményei (Upper Cretaceous and Paleogene formations of the northwest Tiszántúl). - Akadémiai Kiadó, Budapest.

Sztanó, O., G. Tari 1993: Early Miocene basin evolution in Northern Hungary - Tectonics and eustasy. - Tectonophysics, 226, pp. 1485-502.

Tari, G. 1994: Alpine tectonics of the Pannonian basin. - PhD Thesis, Rice University, Texas, USA, $501 \mathrm{p}$.

Tari, G., F. Horváth, J. Rumpler 1992: Styles of extension in the Pannonian Basin. - Tectonophysics, 208, pp. 203-219.

Tari, G., T. Báldi, M. Báldi-Beke 1993: Paleogene retroarc flexural basin beneath the Neogene Pannonian basin: a geodynamic model. - Tectonophysics, 226, pp. 433-455.

Teyssier, C., B. Tikoff, M. Markley 1995: Oblique plate motion and continental tectonics. - Geology, 23, pp. 447-450.

Tomljenović, B., L. Csontos 2001: Neogene-Quaternary structures in the border zone between Alps, Dinarides and Pannonian Basin (Hrvatsko zagorje and Karlovac Basins, Croatia). - International Journal of Earth Sciences, 90, pp. 560-578.

Vörös, A. 1993: Jurassic microplate movements and brachiopod migrations in the western part of the Tethys. - Palaeogeogr., Palaeoclimatol., Palaeoecol., 100, pp. 125-145.

Wein, Gy. 1969: Tectonic review of the Neogene covered areas of Hungary. - Acta Geologica Hungarica, 13, pp. 399-436.

Wein, Gy. 1978: A Kárpátmedence kialakulásának vázlata (Evolution draft of the Carpathian Basin). Általános Földtani Szemle 11, pp. 5-34.

Wu, J.E., K. McClay, P. Whitehouse, T. Dooley 2009: 4D analogue modelling of transtensional pullapart basins. - Marine and Petroleum Geology, 26, pp. 1608-1623. 